\title{
Physicochemical Surface-soil Properties after Litter- removal Manipulation in a Cambodian Lowland Dry Evergreen Forest
}

\author{
Eriko ITO ${ }^{1 *}$, Jumpei TORIYAMA ${ }^{2}$, Makoto ARAKI ${ }^{2}$, Yoshiyuki KIYONO², \\ Mamoru KANZAKI ${ }^{3}$, Bora TITH ${ }^{4}$, Samkol KETH ${ }^{4}$, Ly CHANDARARITY ${ }^{4}$ and \\ Sophal CHANN ${ }^{4}$ \\ ${ }^{1}$ Hokkaido Research Center, Forestry and Forest Products Research Institute (FFPRI) (Sapporo, \\ Hokkaido 062-8516, Japan) \\ ${ }^{2}$ FFPRI (Tsukuba, Ibaraki 305-8687, Japan) \\ ${ }^{3}$ Graduate School of Agriculture, Kyoto University (Kyoto, Kyoto 606-8502, Japan) \\ ${ }^{4}$ Forest and Wildlife Science Research Institute (FWRSI), Forestry Administration (House No. 40 \\ Norodom Boulevard, Phnom Penh, Cambodia)
}

\begin{abstract}
Litter plays key roles in forest ecosystems, and forest degradation is likely to spur a further decline in leaf litterfall inputs to forest soils. However, the effects on physicochemical surface-soil properties remain largely unknown, especially in seasonal tropical forest ecosystems. We initiated a litterremoval manipulation experiment in a Cambodian lowland evergreen forest undergoing intensive selective logging. Litter removal performed for 2 and 4.4 years respectively triggered an increase in bulk density and decrease in surface-soil carbon (C) and nitrogen (N) contents to 67 and $73 \%$ of the original levels, respectively. After only 2 years of treatment, bulk density rose to very high value $\left(>1.40 \mathrm{Mg} \mathrm{m}^{-3}\right)$ likely preventing further soil compaction, while the $\mathrm{C}$ and $\mathrm{N}$ reduction effects lasted over 2 years. Greater soil compaction occurs in stands with a smaller initial bulk density. However, $\mathrm{C}$ (N)-rich soils did not necessarily lose a greater relative proportion of $\mathrm{C}(\mathrm{N})$ than $\mathrm{C}(\mathrm{N})$-poor soils. Although $\mathrm{N}$ remained above $\mathrm{C}$ following the litter removal, conservative trends in the $\mathrm{C}: \mathrm{N}$ ratio suggested a limited capacity for $\mathrm{N}$ retention. Together, our data suggest that shifts in leaf litter inputs in response to localized human disturbances may have rapid and lasting consequences on physicochemical surface-soil properties; possibly accelerated by a tropical climate. Moreover, a speedy recovery to an adequate litter supply, at least before reaching the upper soil compaction limit, is essential to conserve forest ecosystems.
\end{abstract}

Discipline: Soils, fertilizers and plant nutrition

Additional key words: bulk density, carbon, forest degradation, nitrogen, soil compaction

\section{Introduction}

Litter plays two key roles in forest ecosystems: it is a basic component of nutrient and carbon (C) cycling and forms a protective layer over the mineral soil surface, thereby protecting against microclimatic fluctuations, erosion, and soil compaction ${ }^{35,40}$. Removing and adding litter both significantly affect ecosystem-level processes and physicochemical surface-soil properties such as soil temperature, soil water content, the availability of some nutrients, and soil respiration ${ }^{56}$. Traditionally, litter manipulation has aimed to evaluate the effects on nutrient cycles and has been mainly conducted in temperate forests ${ }^{40}$.

More recently and in relation to global climate change, tropical forests have gained recognition for regulating global C fluxes ${ }^{4}$ and stocks ${ }^{13}$. Various experimental approaches have been declared necessary to clarify the mechanisms governing tropical forest ecosystems, making them different from temperate forests ${ }^{60}$. Previous tropical litter manipulation studies have been mainly conducted in the Neotropical region, and almost all studies conducted in Southeast Asia,

This paper reports the results obtained in projects supported in part by KAKENHI 20770021, the Global Environment Research Fund (B-072, B-082), the Research by global environment research coordination system funded by the Ministry of the Environment Japan, and by the emergency project to develop the structure of promoting REDD action supported by the Forestry Agency Japan. *Corresponding author: e-mail iter@fffpri.affrc.go.jp

Received 12 September 2012; accepted 12 August 2013. 
with a few exceptions, have aimed to assess the effects on seed germination, seedling emergence, and survival ${ }^{40,56}$. Accordingly, Asian tropical studies have rarely been included in pantropical research syntheses, other than in a few examples from Thailand ${ }^{36}$.

A large area of seasonal tropical forest remains in Cambodia compared to other countries in the Indochina Peninsula, even under increasing deforestation pressure ${ }^{8-10}$. In particular, Cambodian lowland dry evergreen forest has unique biodiversity ${ }^{61}$ and scarcity, because it has disappeared from other countries of the Indochina Peninsula due to the impact of human development ${ }^{46}$. Moreover, the lowland dry evergreen forest is eco-hydrologically unique due to the abundant groundwater supplied from a large area of the watershed ${ }^{2,3,29}$. By utilizing the groundwater resources stored in a thick soil layer $(>10 \mathrm{~m} \text { deep })^{30}$, year-round active stand transpiration is realized in these forests ${ }^{6}$ even in a highly seasonal environment characterized by a 6-month dry season $^{28}$. There is an urgent need to clarify the influence of anthropogenic change in the lowland dry evergreen forest ecosystem, potentially governed by unique $\mathrm{C}$, nutrient, and water cycles.
Nevertheless, Cambodian ecological data have been lacking in this area for historical reasons. Despite recent intensive investigations into Cambodian forest ecosystems ${ }^{39}$, especially concerning forest soil ${ }^{47-49}$, groundwater resource capacity $^{2,29,51}$, and tree biomass $\mathrm{C}$ stock ${ }^{20,38}$, the linkage between above- and belowground $\mathrm{C}$ stock information remains scant ${ }^{19,53}$. Additionally, information on the effects of forest changes on soil properties mainly concern land-use conversion (e.g. rubber plantations) $)^{50}$, and studies examining the effects of forest degradation are extremely limited.

Accordingly, in this study, we aimed to clarify the effects of litterfall depletion, likely driven by forest degradation, on physicochemical surface-soil properties using litter-removal manipulation in a Cambodian lowland evergreen forest. We also aimed to provide basic data for litter supply, standing floor litter, and soil properties under natural forest conditions to improve the process model for describing $\mathrm{C}$, nutrient, and water dynamics in the ecosystem; both under present conditions, under those of near-future deforestation and/or forest degradation, and those of future global climate change. An improved process model would enable the $\mathrm{CO}_{2}$ emission rate from forest soils during forest degradation to

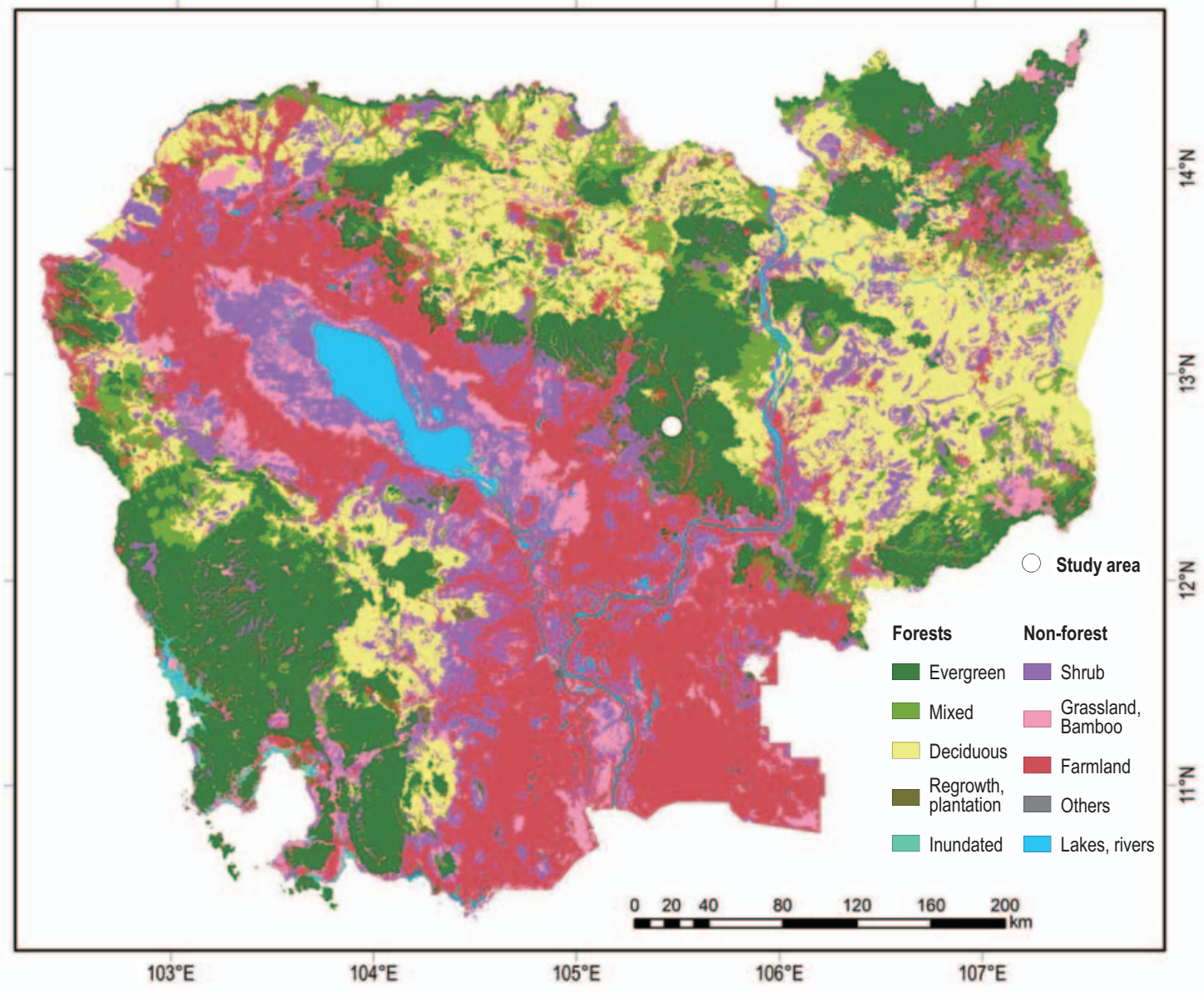

Fig. 1. Location of the study area and a vegetation map of Cambodia

The vegetation map (2002) was provided by the Cambodia forestry administration and the Japan International Cooperation Agency (JICA). 
be predicted more reliably, as part of a scheme to help reduce emissions from deforestation and forest degradation in developing countries (REDD) ${ }^{11}$.

The study objectives included to quantify litterfall and its species composition, provide basic information on the chemical properties of the litter component, characterize the chemical soil properties in terms forest floor litter conditions in the Cambodian lowland evergreen forest, and determine the extent to which litter supply limitation influences physicochemical soil properties by examining litter-removal treatments over $>2$ years.

\section{Study Site}

The study site was located in Kampong Thom Province, central Cambodia (12 $76^{\prime} \mathrm{N}, 105^{\circ} 48^{\prime} \mathrm{E}$; Fig. 1). This is a lowland dry evergreen forest covering a flat and gently rolling alluvial plain, with an elevation of 60-100 m a.s.l. The dry evergreen forest in Kampong Thom is one of the last remaining lowland evergreen forests on the Indochina Peninsula. The top-layered trees at the study site were Dipterocarpus costatus C.F. Gaertn. and Anisoptera costata Korth. (Dipterocarpaceae) ${ }^{34,46}$, which are undergoing rapid degradation due to intensive illegal logging. Almost all trees more than $60 \mathrm{~cm}$ in diameter at breast height (DBH) along logging roads have been logged in the area. The logging density was 5.4 trees $^{-1}$ year $^{-1}$ from November 2006 to March 2008 (Furuya et al., personal correspondence).

The subtropical climate of the research area is governed by two monsoons: the cool and dry northeastern monsoon from November to March and the humid southwestern monsoon from May to October ${ }^{16}$. In 2004, the annual precipitation was $>1542.8 \mathrm{~mm}$ at the nearest meteorological observation site (data were lacking from 1 January to 25 April) and 1434.4-1565.4 $\mathrm{mm}$ at another station located within a $30 \mathrm{~km}$ radius. Over $90 \%$ of precipitation occurs during the rainy season. The monthly average temperatures ranged from 26.8 to $30.2^{\circ} \mathrm{C}$ in $2003^{16}$.

The geology of the region is characterized extensively as quaternary sedimentary rock $^{58}$, and topsoils are generally slightly coarser than deeper layers ${ }^{47}$. Soils in the dry evergreen forest are typically sandy Acrisols, characterized by acidity, low base saturation, the translocation of clay, and low CEC/clay, and classified as Haplic Acrisols (Alumic, Profondic) and Kanhaplic Haplustult in the World Reference Base system and US Soil Taxonomy System, respectively $^{47,48}$.

\section{Methods}

\section{Experimental litter-removal plots}

The litter-removal experiment was conducted in 12 plots within a $100 \mathrm{~m} \times 1.8-\mathrm{km}$ rectangle; characterized by gently undulating topography. Each plot comprised a pair of two subplots, each with an area of $50 \times 50 \mathrm{~cm}$ and designated as litter-removal (LR) and control (CTRL) respectively. Each pair of LR and CTRL subplots was located within a radius of $2 \mathrm{~m}$ in an undisturbed area of similar microtopography. Among the 12 plots, 8 were inside stands with tall dipterocarp trees, whereas 4 were located in stands without any dipterocarp trees; within a radius of $20 \mathrm{~m}$ of each subplot. The major tree species in each plot are listed in Appendix 1. At a distance of $20 \mathrm{~m}$ from plots 5-8, a 2$\mathrm{m}$-depth soil profile investigation was conducted in May 2003. Details and a comparative study of the soil profile have been reported elsewhere and described as DEF $1^{47}, \mathrm{KH}-$ $\mathrm{E} 1^{48}, \mathrm{KPT}_{2}{ }^{51}$, and one of the four profiles of EFS over sedimentary rocks ${ }^{53}$.

\section{Litter-removal treatment for LR subplots}

Treatments were carried out in the LR subplots over 53 and 24 months in plots 1-4 (October 2004-February 2009) and 5-12 (March 2007-February 2009) respectively. Litter was removed by hand three times per month, then ovendried, sorted (leaves of tall dipterocarp, dominant, and other tree species, branches, and reproductive organs), and weighed. The litter samples collected from plots $1-4$ and 5-12 were mistakenly each combined into single samples. For plots 9-12, the litter samples were treated separately.

\section{Litter sampling and analysis for CTRL subplots}

Forest floor litter was collected from CTRL subplots at the end of February 2009 prior to the surface-soil sampling described below, during the late phase of the leaf shedding season, hence a relatively large amount of standing litter was expected. The litter samples were oven-dried, sorted [litter (L-) layer, fermenting (F-) layer, branches, and reproductive organs], and weighed. The litter layer was further divided into leaves of tall and potentially logged tree species (hereafter, "overstory-logged"; e.g. Dipterocarpus costatus, Anisoptera costata, Sindora siamensis), tall rarely logged tree species ("overstory-unlogged"; e.g. Irvingia malayana, Myristica iners), and the other mid- or lower-layer component species (understory).

The total $\mathrm{C}$ and nitrogen $(\mathrm{N})$ contents of litter samples were determined using an elemental analyzer (vario Max; Elementar, Hanau, Germany). For some overstory and major understory species, the $\mathrm{C}$ and $\mathrm{N}$ contents of fresh leaf litter were measured separately. Litter layer samples of other species and F-layer leaf particle samples were combined for each plot, while branch samples from plots 1-4, 5-8, and 9-12 were combined, as were reproductive organ samples from all plots. Fine-root, coarse-root, and organicmatter samples from the LR subplots and CTRL subplots of plots $1-4,5-8$, and 9-12 were combined, while coarse-root samples from the LR subplots and CTRL subplots of plots 
9-12 were combined due to insufficient sample amounts (Appendix 2).

The $\mathrm{C}$ supply for the LR subplots and the $\mathrm{C}$ stock in the forest floor of the CTRL subplots were determined by multiplying the $\mathrm{C}$ content and litter mass of each litter part. The $\mathrm{C}$ stock was also obtained. Owing to missing data for the LR branch samples, the total C supply was underestimated in all plots. The leaf-litter $\mathrm{C}$ supply in plot 11 was also underestimated due to a missing litter sample for the period from 10-20 December, 2008.

\section{Surface-soil sampling and analysis for LR and CTRL subplots}

Three surface mineral soil cores $(0-5 \mathrm{~cm}$ deep) were collected from each LR and CTRL subplot using a $100-\mathrm{cm}^{3}$ steel cylinder at the end of February 2009 and during the late dry season. All 72 soil cores were collected on the same day and each soil sample core was treated separately throughout the sample preparation and physicochemical analyses. Each soil sample core was weighed, then spread out and dried inside in the open air. After air-drying, each soil core sample was sieved through a $2-\mathrm{mm}$ sieve and divided into fine mineral soil (diameter $<2 \mathrm{~mm}$ ), stones, fine roots (diameter $<2 \mathrm{~mm}$ ), coarse roots (diameter $>2$ $\mathrm{mm}$ ), and organic particles. Each sample was then ovendried $\left(105^{\circ} \mathrm{C}, 24 \mathrm{~h}\right)$ and weighed.

The bulk density of each soil core sample was calculated as the oven-dried weight of fine soil material per volume. Volumetric soil water content was calculated using the fresh and oven-dried weights of fine soil, whereupon the gravimetric soil water content was calculated from these measurements.

Total $\mathrm{C}$ and $\mathrm{N}$ contents were determined for mineral soil, fine roots, coarse roots, and organic particles using the vario Max Elementar. The $\mathrm{C}$ and $\mathrm{N}$ contents of the mineral soil in each sample core were measured separately, whereas the roots and organic particles in the mineral soil samples from plots $\mathrm{A}, \mathrm{B}$, and $\mathrm{C}$ were combined to obtain analyzable sample amounts (Appendix 2).

Mass-based soil C stock was obtained for comparison between LR and CTRL plots. Soil C stocks in CTRL plots were calculated by multiplying the $\mathrm{C}$ content and bulk density (i.e. a depth-based approach). In the LR plots, soil C stocks were adjusted according to the difference in mass of the soil mineral fraction between LR and CTRL plots ${ }^{52}$. C stocks in the coarse roots, fine roots, and organic particles were evaluated as non-soil belowground $\mathrm{C}$ stock. Total belowground $\mathrm{C}$ stock was obtained as the sum of soil and non-soil C stock.

\section{Statistical analysis}

To compare the mean soil properties between LR and CTRL plots, a randomized split plot design with three repli- cates (soil cores) was used. A repeated measures analysis of variance (ANOVA) was conducted for soil properties with plots as a subject term, treatments (LR or CTRL) as a within-subject treatment term, and their interactions as a random effect term. Tukey's honestly significant difference (HSD) tests were used to distinguish significant differences at $\mathrm{P}<0.05$. To assess relationships among litter layer and soil variables collected for each CTRL subplot, we calculated the Pearson product-moment correlations. Relationships among soil and non-soil variables for each soil core collected from both CTRL and LR plots were also investigated using Pearson's correlations. In all cases, we checked for nonlinear relationships and transformed data using $\ln$ transformations as necessary using a significance threshold of $P=0.05$. Linear regression analysis was used to assess whether the relative difference in soil properties (soil bulk density, soil $\mathrm{C}$ content, and soil $\mathrm{N}$ content) between the CTRL and LR plots correlated with soil properties in the CTRL plot. All statistical analysis was conducted using JMP ver. 6.0.3 (SAS Institute Inc., Cary, NC, USA).

\section{Results}

\section{Forest floor $C$ stock and litter fall $C$ supply}

The forest floor C stock in CTRL plots averaged 3.09 $\pm 1.12 \mathrm{Mg} \mathrm{C} \mathrm{ha}^{-1}$ (Table 1), whereby the L-layer, F-layer, branches, and reproductive organs contributed 34, 15, 47, and $4 \%$, respectively, of the total forest floor $\mathrm{C}$ stock.

The variation in forest floor $\mathrm{C}$ stock was mainly due to variation in branch $\mathrm{C}$ stock $\left(1.63 \pm 1.21 \mathrm{Mg} \mathrm{C} \mathrm{ha}^{-1}\right.$; Table $1)$, which coincided with a strong correlation between the forest floor $\mathrm{C}$ stock and the branch $\mathrm{C}$ stock $(\mathrm{P}<0.0001$; Table 2a). As for leaf litter, less variation was found in the $\mathrm{C}$ stock of the understory species in the L-layer $(0.56 \pm 0.18$ $\mathrm{Mg} \mathrm{C} \mathrm{ha-1),} \mathrm{while} \mathrm{much} \mathrm{of} \mathrm{the} \mathrm{variation} \mathrm{was} \mathrm{found} \mathrm{in} \mathrm{the} \mathrm{C}$ stock sourced from overstory tree species $(0.42 \pm 0.44 \mathrm{Mg}$ $\mathrm{C} \mathrm{ha}^{-1}$; Table 1). The L-layer $\mathrm{C}$ stocks were correlated with $\mathrm{C}$ stocks in leaves of the overstory-logged species and $\mathrm{C}$ stocks of the reproductive organs $(\mathrm{P}<0.01)$. However, $\mathrm{C}$ stocks in the reproductive organs were also correlated with $\mathrm{C}$ stocks in leaves of overstory-logged species (Table 2a). The correlation coefficients between L- and F-layer C stocks were negative, but not significantly (Table $2 \mathrm{a}$ ).

The mean annual $\mathrm{C}$ supply via leaf litterfall for the LR subplots ranged from 1.9 to $4.5 \mathrm{Mg} \mathrm{C} \mathrm{ha}^{-1}$, while those via total litterfall ranged from 1.9 to $5.6 \mathrm{Mg} \mathrm{C} \mathrm{ha}^{-1}$ (Appendix 3 ). The annual total leaf-litter supply varied less compared to the leaf-litter supply divided into three categories (overstory-logged, overstory-unlogged, and understory). A total of $29 \pm 10$ and $11 \pm 9 \%$ of annual leaf-litter C supply for the LR subplots corresponded to L- and F-layer C stocks, respectively, in the CTRL subplots. 
Table 1. Mean carbon (C) stock $\left(\mathrm{Mg} \mathrm{C} \mathrm{ha}^{-1}\right)$ in the forest floor of the control (CTRL) subplots

\begin{tabular}{|c|c|c|c|c|c|c|c|c|c|}
\hline \multirow[b]{3}{*}{ Plot } & \multicolumn{9}{|c|}{ Forest floor components $\left[\mathrm{Mg} \mathrm{C}^{-1}\right]$} \\
\hline & \multicolumn{5}{|c|}{ L layer } & \multirow{2}{*}{ F-layer } & \multirow{2}{*}{ Branches } & \multirow{2}{*}{$\begin{array}{l}\text { Reproductive } \\
\text { organs }\end{array}$} & \multirow{2}{*}{$\begin{array}{l}\text { Total } \\
\text { forest floor }\end{array}$} \\
\hline & $\begin{array}{c}\text { Overstory- } \\
\text { logged }\end{array}$ & $\begin{array}{l}\text { Overstory- } \\
\text { unlogged }\end{array}$ & $\begin{array}{c}\text { Total } \\
\text { Overstory }\end{array}$ & Understory & $\begin{array}{c}\text { Total } \\
\text { L-layer }\end{array}$ & & & & \\
\hline 1 & 0.83 & 0.00 & 0.83 & 0.50 & 1.32 & 0.14 & 2.51 & 0.39 & 4.36 \\
\hline 2 & 0.42 & 0.00 & 0.42 & 0.40 & 0.82 & 0.11 & 0.57 & 0.13 & 1.63 \\
\hline 3 & 0.66 & 0.00 & 0.66 & 0.67 & 1.33 & 0.30 & 1.23 & 0.25 & 3.12 \\
\hline 4 & 1.31 & 0.00 & 1.31 & 0.33 & 1.64 & 0.08 & 0.84 & 0.58 & 3.14 \\
\hline 5 & 0.12 & 0.00 & 0.12 & 0.60 & 0.72 & 0.17 & 3.12 & 0.00 & 4.00 \\
\hline 6 & 0.10 & 0.00 & 0.10 & 0.74 & 0.84 & 0.34 & 3.91 & 0.00 & 5.09 \\
\hline 7 & 0.36 & 0.00 & 0.36 & 0.31 & 0.67 & 0.15 & 1.80 & 0.00 & 2.62 \\
\hline 8 & 0.19 & 0.00 & 0.19 & 0.78 & 0.97 & 0.41 & 2.89 & 0.01 & 4.28 \\
\hline 9 & 0.00 & 1.00 & 1.00 & 0.35 & 1.34 & 0.54 & 0.56 & 0.00 & 2.44 \\
\hline 10 & 0.00 & 0.06 & 0.06 & 0.82 & 0.87 & 0.94 & 0.41 & 0.00 & 2.23 \\
\hline 11 & 0.00 & 0.00 & 0.00 & 0.57 & 0.57 & 0.49 & 1.42 & 0.00 & 2.49 \\
\hline 12 & 0.00 & 0.00 & 0.00 & 0.63 & 0.63 & 0.71 & 0.32 & 0.00 & 1.66 \\
\hline Total & $0.33 \pm 0.41$ & $0.09 \pm 0.29$ & $0.42 \pm 0.44$ & $0.56 \pm 0.18$ & $0.98 \pm 0.35$ & $0.37 \pm 0.27$ & $1.63 \pm 1.21$ & $0.11 \pm 0.19$ & $3.09 \pm 1.12$ \\
\hline
\end{tabular}

Table 2a. Pearson correlations between measured variables for the forest floor and below ground (a) Correlations among forest floor properties and between forest floor and belowground properties for the CTRL subplots $(n=12)$

\begin{tabular}{|c|c|c|c|c|c|c|c|c|}
\hline \multirow[b]{3}{*}{ Variable } & \multicolumn{8}{|c|}{ Forest floor C stocks } \\
\hline & \multicolumn{3}{|c|}{ Leaf litter in the L layer } & \multirow[b]{2}{*}{$\begin{array}{c}\text { Total } \\
\text { L-layer }\end{array}$} & \multirow[b]{2}{*}{ F-layer } & \multirow[b]{2}{*}{ Branches } & \multirow[b]{2}{*}{$\begin{array}{c}\text { Reproductive } \\
\text { organs }\end{array}$} & \multirow[b]{2}{*}{$\begin{array}{l}\text { Total forest } \\
\text { floor }\end{array}$} \\
\hline & $\begin{array}{l}\text { Overstory- } \\
\text { logged }\end{array}$ & $\begin{array}{l}\text { Overstory- } \\
\text { unlogged }\end{array}$ & Understory & & & & & \\
\hline \multicolumn{9}{|l|}{ Forest floor C stocks } \\
\hline Overstory-logged & 1 & & & & & & & \\
\hline Overstory-unlogged & -0.27 & 1 & & & & & & \\
\hline Understory & -0.45 & -0.34 & 1 & & & & & \\
\hline Total L-layer & $0.74 * *$ & 0.33 & -0.29 & 1 & & & & \\
\hline F-layer & $-0.66 *$ & 0.25 & 0.57 & -0.29 & 1 & & & \\
\hline Branches & -0.06 & -0.30 & 0.32 & -0.15 & -0.39 & 1 & & \\
\hline Reproductive organs & $0.97 * * * *$ & -0.20 & -0.38 & $0.80 * *$ & -0.53 & -0.13 & 1 & \\
\hline Total forest floor & 0.18 & -0.20 & 0.33 & 0.22 & -0.36 & $0.92 * * * *$ & 0.15 & 1 \\
\hline \multicolumn{9}{|l|}{ Soil physical properties } \\
\hline Bulk density & 0.26 & 0.32 & -0.46 & 0.35 & -0.50 & 0.15 & 0.30 & 0.20 \\
\hline Gravimetric soil water content & -0.38 & -0.30 & 0.31 & -0.54 & $0.59 *$ & -0.37 & -0.27 & -0.47 \\
\hline Volumetric soil water content & -0.33 & -0.26 & 0.20 & -0.51 & 0.46 & -0.31 & -0.23 & -0.42 \\
\hline \multicolumn{9}{|l|}{ Belowground $\mathrm{C}$ and $\mathrm{N}$ contents } \\
\hline Soil C content & -0.39 & -0.27 & $0.63 *$ & -0.36 & $0.70 *$ & -0.12 & -0.37 & -0.13 \\
\hline Soil N content & -0.24 & -0.31 & $0.58 *$ & -0.24 & 0.39 & 0.15 & -0.29 & 0.13 \\
\hline $\mathrm{C}: \mathrm{N}$ ratio & -0.48 & -0.24 & 0.57 & -0.47 & $0.83 * * *$ & -0.30 & -0.40 & -0.34 \\
\hline \multicolumn{9}{|l|}{ Belowground C stocks } \\
\hline Soil & -0.42 & -0.32 & $0.68 *$ & -0.41 & $0.67 *$ & 0.00 & -0.39 & -0.03 \\
\hline Belowground total & -0.42 & -0.43 & $0.67 *$ & -0.51 & $0.64 *$ & -0.13 & -0.39 & -0.21 \\
\hline Coarse roots $(>2 \mathrm{~mm})$ & -0.17 & -0.24 & 0.09 & -0.36 & 0.05 & -0.24 & -0.16 & -0.39 \\
\hline Fine roots $(<2 \mathrm{~mm})$ & -0.53 & -0.36 & 0.39 & $-0.73 * *$ & 0.48 & -0.15 & -0.52 & -0.37 \\
\hline Organic particles & 0.29 & -0.28 & 0.36 & 0.30 & 0.27 & -0.20 & 0.30 & -0.01 \\
\hline \multicolumn{9}{|l|}{ Belowground N stocks } \\
\hline Belowground total & -0.14 & -0.39 & 0.54 & -0.21 & 0.13 & 0.35 & -0.20 & 0.31 \\
\hline Soil N stock $(0-5 \mathrm{~cm})$ & -0.08 & -0.25 & 0.44 & -0.08 & 0.05 & 0.41 & -0.14 & 0.41 \\
\hline
\end{tabular}




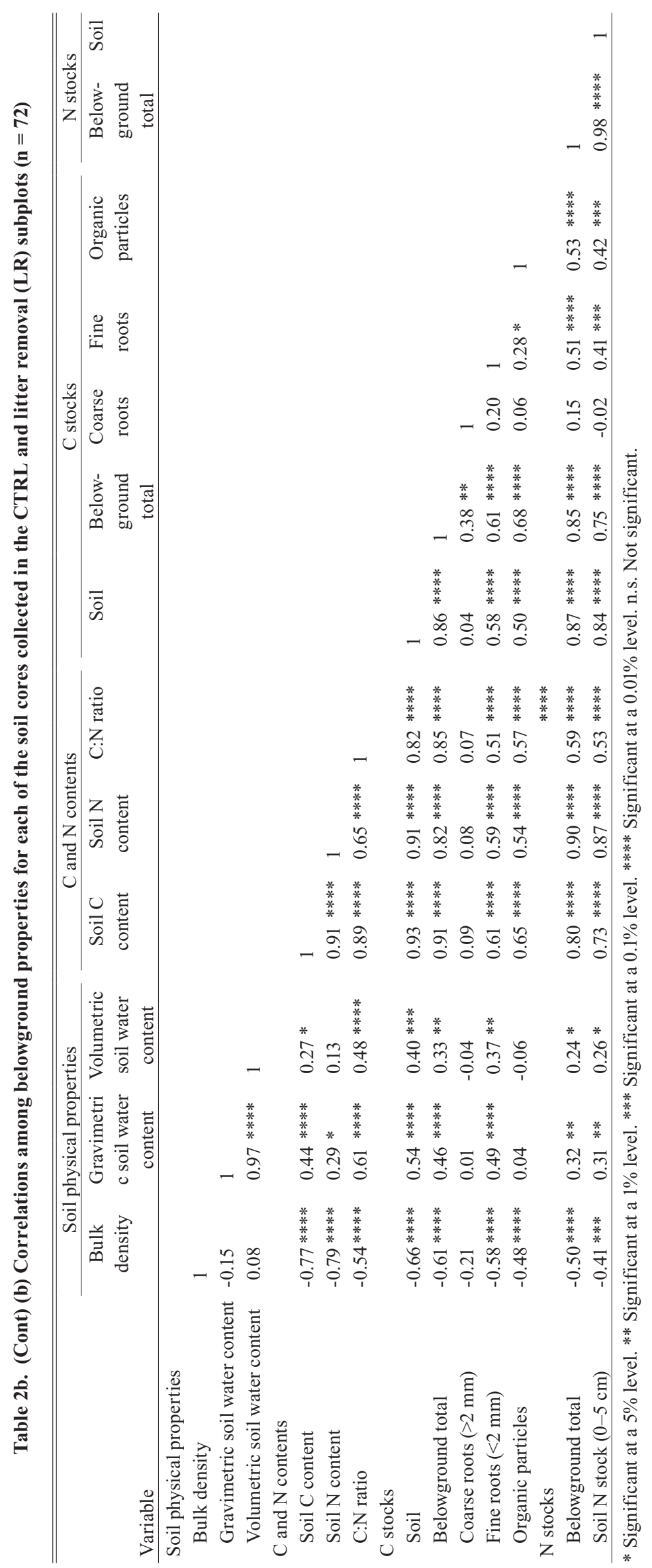

\section{Litter-removal experiment}

Litter removal had significant effects on bulk density, gravimetric and volumetric soil water content, soil C content, mass- and depthbasis soil $\mathrm{C}$ stocks, belowground total $\mathrm{C}$ stock, fine root $\mathrm{C}$ stock, soil $\mathrm{N}$ content, soil $\mathrm{N}$ stock, belowground total $\mathrm{N}$ stock, and $\mathrm{C}: \mathrm{N}$ ratio, but no significant effect on $\mathrm{C}$ stocks in coarse roots and organic particles (treatment term; Table 3).

\section{Bulk density and soil water content}

The bulk density of soils was significantly higher in the LR subplots (mean $\pm \mathrm{SD}, 1.46 \pm$ $\left.0.08 \mathrm{Mg} \mathrm{m}^{-3}\right)$ than in the CTRL subplots $(1.25$ $\pm 0.14 \mathrm{Mg} \mathrm{m}^{-3}, \mathrm{P}<0.0001$; Tables 3 and 4). Comparing the LR and CTRL of each plot, the difference was significant in 4 of the 12 plots that displayed relatively lower CTRL bulk density (Table 4). The relative difference in bulk density significantly increased with decreasing CTRL bulk density (linear regression analysis: d.f. $=11 ; \mathrm{R}^{2}=0.90, \mathrm{P}<0.0001$; Fig. 2a). However, the 4.4 years of manipulation experiments showed no clearly different trend from the 2 years of manipulation plots.

Forest floor C stock properties did not correlate significantly with the bulk density in CTRL plots (Table 2a). Although bulk density correlated negatively with almost all $\mathrm{C}$ and $\mathrm{N}$ properties, soil water content and coarse-root $\mathrm{C}$ stock did not correlate with bulk density in the CTRL and LR plots (Table 2b).

The gravimetric soil water content was significantly lower in the LR subplots (mean \pm $\mathrm{SD}, 7.2 \pm 4.5 \%)$ than the CTRL subplots $(8.0 \pm$ $5.0 \%, \mathrm{P}<0.0001$; Tables 3 and 4). Compared to the LR and CTRL within each plot, a significantly lower soil water content in LR was found in only 1 of the 12 plots (10). The trend in terms of volumetric soil water content was opposite and rather vague, whereby significantly higher values were observed in the LR subplots (mean $\pm \mathrm{SD}, 11.7 \pm 8.7 \%$ ) compared to the CTRL subplots $(11.0 \pm 8.0 \%, \mathrm{P}<0.05$; Tables 3 and 4).

The gravimetric soil water content correlated positively with the F-layer $\mathrm{C}$ stock $(\mathrm{P}<$ 0.05 ), while displaying negative trends with the L-layer $\mathrm{C}$ stock and the total forest floor $\mathrm{C}$ stock $(\mathrm{P}<0.05$ in all cases). Conversely, the volumetric soil water content did not correlate with any forest floor $\mathrm{C}$ stock variable (Table 2a). Both soil water content indices correlated 
Table 3. Analysis of variance (split plot design) of the soil properties

\begin{tabular}{|c|c|c|c|c|c|c|c|c|c|c|c|c|c|c|c|}
\hline \multirow[b]{2}{*}{ Source } & \multirow[b]{2}{*}{ d.f. } & \multirow{2}{*}{$\begin{array}{c}\text { Bulk } \\
\text { density }\end{array}$} & \multirow{2}{*}{\multicolumn{2}{|c|}{$\begin{array}{c}\text { Gravime Volumet } \\
\text { tric soil ric soil } \\
\text { water water } \\
\text { content content }\end{array}$}} & \multirow{2}{*}{$\begin{array}{l}\text { Soil C } \\
\text { content }\end{array}$} & \multicolumn{6}{|c|}{ C stock } & \multirow[b]{2}{*}{$\begin{array}{l}\text { Soil N } \\
\text { content }\end{array}$} & \multicolumn{2}{|c|}{$\mathrm{N}$ stock } & \multirow[b]{2}{*}{$\begin{array}{l}\mathrm{C}: \mathrm{N} \\
\text { ratio }\end{array}$} \\
\hline & & & & & & $\begin{array}{c}\text { Soil } \\
\text { (mass- } \\
\text { basis) }\end{array}$ & $\begin{array}{c}\text { Soil } \\
\text { (depth- } \\
\text { basis) }\end{array}$ & $\begin{array}{c}\text { Belowgr } \\
\text { ound } \\
\text { total }\end{array}$ & $\begin{array}{c}\text { Coarse } \\
\text { roots }\end{array}$ & $\begin{array}{l}\text { Fine } \\
\text { roots }\end{array}$ & $\begin{array}{l}\text { Organic } \\
\text { particles }\end{array}$ & & $\begin{array}{c}\text { Soil } \\
\text { (depth- } \\
\text { basis) }\end{array}$ & $\begin{array}{c}\text { Belowgr } \\
\text { ound } \\
\text { total }\end{array}$ & \\
\hline Treatment & 1 & $* * * *$ & $* * * *$ & $*$ & $* * * *$ & $* * * *$ & $* * * *$ & $* * * *$ & n.s. & $* * * *$ & n.s. & $* * * *$ & $* * * *$ & $* * * *$ & $* * * *$ \\
\hline Plot & 11 & $* * * *$ & $* * * *$ & $* * * *$ & $* * * *$ & $* * * *$ & $* * * *$ & $* * * *$ & n.s. & $* * * *$ & $* * * *$ & $* * * *$ & $* * * *$ & $* * * *$ & $* * * *$ \\
\hline Plot $\times$ Treatment & 11 & n.s. & $* * * *$ & $* * *$ & $* * *$ & $* * *$ & $* * * *$ & $* *$ & $*$ & n.s. & n.s. & $* * * *$ & $* * * *$ & $* * * *$ & n.s. \\
\hline
\end{tabular}

* Significant at a $5 \%$ level. $* *$ Significant at a $1 \%$ level. $* * *$ Significant at a $0.1 \%$ level. $* * *$ Significant at a $0.01 \%$ level. n.s. Not significant.

Table 4. Bulk density and soil water contents in the litter removal (LR) and control (CTRL) subplots

\begin{tabular}{ccccccc}
\hline \hline & \multicolumn{2}{c}{$\begin{array}{c}\text { Bulk density } \\
{\left[\mathrm{Mg} \mathrm{m}^{-3}\right]}\end{array}$} & \multicolumn{2}{c}{ Gravimetric soil water content } & \multicolumn{2}{c}{ Volumetric soil water content } \\
Plot & LR & CTRL & LR & CTRL & LR & CTRL \\
\hline 1 & $1.57 \pm 0.04$ & $1.35 \pm 0.04$ & $5.5 \pm 0.5$ & $5.4 \pm 0.5$ & $9.1 \pm 0.6$ & $7.6 \pm 0.8$ \\
2 & $1.50 \pm 0.07$ & $1.29 \pm 0.09$ & $3.7 \pm 0.7$ & $5.0 \pm 1.3$ & $5.8 \pm 1.3$ & $6.7 \pm 1.5$ \\
3 & $1.52 \pm 0.04$ & $1.32 \pm 0.13$ & $4.9 \pm 0.3$ & $6.3 \pm 0.5$ & $7.9 \pm 0.4$ & $8.9 \pm 1.2$ \\
4 & $1.52 \pm 0.03$ & $1.31 \pm 0.10$ & $4.2 \pm 0.1$ & $6.0 \pm 0.4$ & $6.6 \pm 0.2$ & $8.4 \pm 1.2$ \\
5 & $1.42 \pm 0.09$ & $1.20 \pm 0.06$ & $5.3 \pm 0.5$ & $5.5 \pm 0.2$ & $8.0 \pm 1.1$ & $7.0 \pm 0.3$ \\
6 & $1.43 \pm 0.02$ & $1.35 \pm 0.04$ & $4.8 \pm 0.3$ & $4.8 \pm 0.2$ & $7.2 \pm 0.4$ & $6.9 \pm 0.1$ \\
7 & $1.41 \pm 0.11 *$ & $1.16 \pm 0.05$ & $5.8 \pm 0.2$ & $6.2 \pm 0.5$ & $8.6 \pm 0.9$ & $7.6 \pm 0.4$ \\
8 & $1.42 \pm 0.11 *$ & $1.17 \pm 0.09$ & $5.8 \pm 0.9$ & $5.7 \pm 0.2$ & $8.7 \pm 1.0$ & $7.0 \pm 0.4$ \\
9 & $1.45 \pm 0.03$ & $1.42 \pm 0.01$ & $5.1 \pm 0.6$ & $2.9 \pm 0.3$ & $7.8 \pm 0.8$ & $4.2 \pm 0.5$ \\
10 & $1.26 \pm 0.09 *$ & $0.88 \pm 0.09$ & $7.3 \pm 0.4 *$ & $12.3 \pm 1.2$ & $9.9 \pm 0.2$ & $12.3 \pm 1.5$ \\
11 & $1.52 \pm 0.11$ & $1.35 \pm 0.13$ & $17.4 \pm 0.1$ & $18.6 \pm 0.7$ & $31.9 \pm 2.0$ & $30.7 \pm 3.3$ \\
12 & $1.48 \pm 0.04 *$ & $1.23 \pm 0.04$ & $16.5 \pm 0.9$ & $17.0 \pm 0.5$ & $29.4 \pm 1.5 *$ & $25.1 \pm 1.6$ \\
Total & $1.46 \pm 0.08$ & $1.25 \pm 0.14$ & $7.2 \pm 4.5$ & $8.0 \pm 5.0$ & $11.7 \pm 8.7$ & $11.0 \pm 8.0$ \\
\hline
\end{tabular}

Mean $\pm \mathrm{SD}, \mathrm{n}=3$. Asterisk $(*)$ indicates a significant difference between LR and CTRL subplots.

strongly and positively with soil $\mathrm{C}$ properties and, to a lesser degree, with soil $\mathrm{N}$ properties (Table $2 \mathrm{~b}$ ). The fine root $\mathrm{C}$ stock correlated positively with the soil water content indices, while the other non-soil belowground C stocks (i.e. coarse roots and organic particles) did not correlate with water content (Table $2 b)$.

\section{Soil carbon stock}

The $\mathrm{C}$ content of soils was significantly lower in the LR subplots $\left(10.2 \pm 5.5 \mathrm{mg} \mathrm{C} \mathrm{g}\right.$ dry soil $\left.{ }^{-1}\right)$ than in the CTRL subplots $\left(14.6 \pm 5.3 \mathrm{mg} \mathrm{C}\right.$ g dry soil ${ }^{-1}, \mathrm{P}<0.0001$; Tables 3 and 5). On average, the $\mathrm{C}$ content of the LR subplot was $67 \%$ of the CTRL subplot. The average proportion of the $\mathrm{C}$ content in the LR subplot to the CTRL subplot in the 4.4 years of manipulation (plots 1-4) was $60 \%$, as opposed to $71 \%$ in the 2 -year manipulation plots $(5-12)$. When the LR and CTRL were compared within each plot, the difference was significant in 5 of the 12 plots (Table 5). The relative difference in soil $\mathrm{C}$ content did not correlate significantly with the CTRL soil C content (linear regression analysis; Fig. 2b).

The mass-basis soil $\mathrm{C}$ stock $(0-5 \mathrm{~cm}$ depth) in the LR subplots $\left(6.0 \pm 2.3 \mathrm{Mg} \mathrm{C} \mathrm{ha}^{-1}\right)$ was lower than that in the
CTRL subplots $\left(8.8 \pm 2.1 \mathrm{Mg} \mathrm{C}^{-1}\right)$, whereby the difference was significant $(\mathrm{P}<0.0001$; Tables 3 and 5). Comparing the LR and CTRL within each plot, the LR had $67 \%$ of the mass-basis soil C stock of the CTRL on average, and the difference was significant in 5 of the 12 plots (Table 5). The percentage of the CTRL soil C stock represented by the LR C stock and the significant difference between the LR and CTRL within each plot were identical across manipulations due to the calculation method used.

When using a depth-basis approach, the $\mathrm{C}$ content of the LR subplots $\left(7.3 \pm 3.3 \mathrm{MgC} \mathrm{ha}^{-1}\right)$ was also significantly lower than in the CTRL subplots $(\mathrm{P}<0.0001$; Tables 3 and 5). Comparing the LR and CTRL within each plot, the LR had an average $80 \%$ of the depth-basis soil C stock of the CTRL. A significant difference within each plot was found in 3 of the 12 plots, whereby a significantly lower soil C stock was found in the LR over the CTRL in 2 of the 12 plots, while a greater soil C stock in the LR over the CTRL was found in only 1 plot (Table 5). The 4.4-year manipulation plots $(70 \%)$ showed greater $\mathrm{C}$ depletion compared with the 2-year manipulation plots (85\%).

Soil C content, soil C stocks, and belowground total C stocks correlated positively with $\mathrm{C}$ stocks in the leaf litter of 


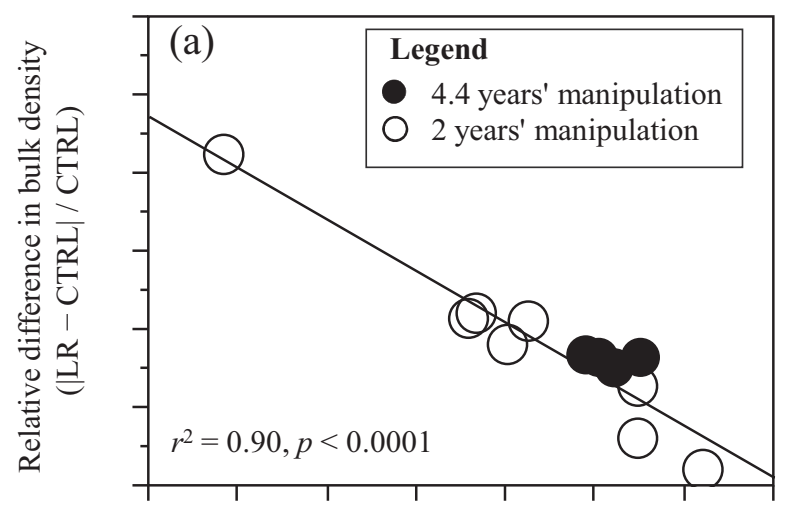

CTRL Bulk density $\left[\mathrm{Mg} \mathrm{m}^{-3}\right]$

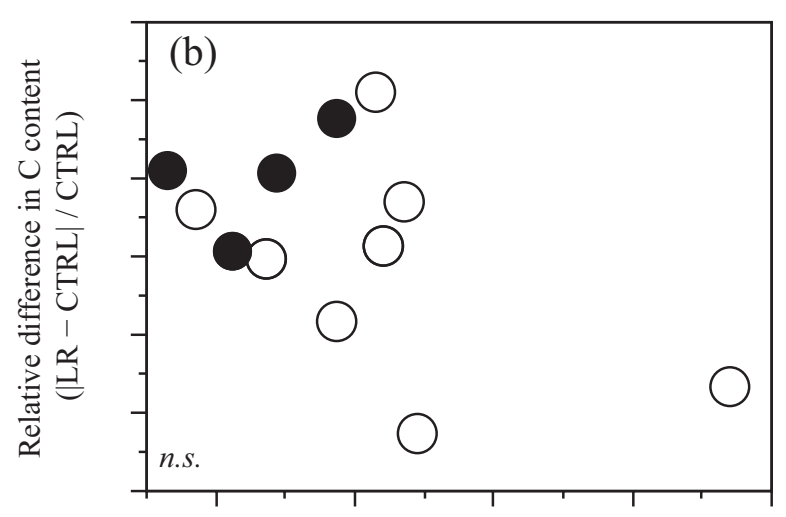

CTRL C content [mg C g dry soil ${ }^{-1}$ ]

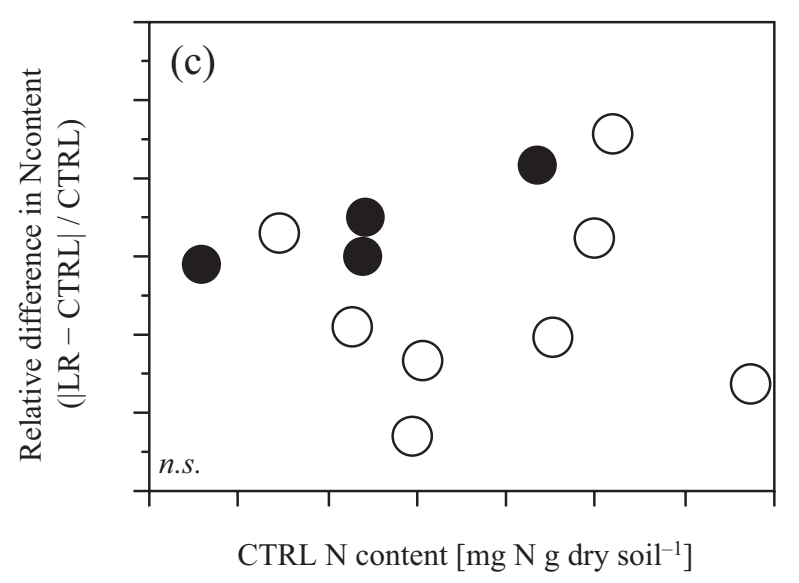

Fig. 2. Relationships of physicochemical soil properties between the control (CTRL) subplots and the litter removal (LR) subplots

(a) Bulk density; (b) soil carbon content; and (c) soil nitrogen content.

understory species and with the F-layer $\mathrm{C}$ stocks $(\mathrm{P}<0.05$ in all cases), but not with the total L-layer or total forest floor C stocks (Table 2a).

Belowground $\mathrm{C}$ properties correlated well with each other ( $\mathrm{P}<0.0001$ in almost all cases), but the coarse-root $\mathrm{C}$ stock only correlated with belowground total $\mathrm{C}$ stock at a lower level of significance $(\mathrm{P}<0.01$; Table $2 \mathrm{~b})$.

\section{Non-soil belowground carbon stocks}

Non-soil belowground C stocks (i.e. C stocks in coarse roots, fine roots, and organic particles) contributed $18.6 \pm$ $10.1 \%$ and $15.2 \pm 9.1 \%$ of the total belowground $\mathrm{C}$ stocks in the CTRL and LR, respectively. Only C stocks in the fine roots were significantly lower in the LR subplots $(0.6 \pm 0.3$ $\left.\mathrm{Mg} \mathrm{C} \mathrm{ha}{ }^{-1}\right)$ than in the CTRL subplots $\left(0.9 \pm 0.4 \mathrm{Mg} \mathrm{C} \mathrm{ha}^{-1}\right.$, $\mathrm{P}<0.0001$; Tables 3 and 6). No significant difference was found in each non-soil belowground $\mathrm{C}$ stock compartments between the LR and CTRL subplots within a plot (Table 6).

A slight significant positive correlation was observed between forest floor $\mathrm{C}$ stock properties and non-soil belowground $\mathrm{C}$ stocks, except for a negative correlation between the fine root $\mathrm{C}$ stock and the L-layer $\mathrm{C}$ stock (Table $2 \mathrm{a}$ ).

\section{6. $N$ content and $C: N$ ratio}

The $\mathrm{N}$ content of soils was significantly lower in the LR subplots $\left(0.61 \pm 0.17 \mathrm{mg} \mathrm{N} \mathrm{g} \mathrm{dry} \mathrm{soil}{ }^{-1}\right)$ than the CTRL subplots $\left(0.84 \pm 0.18 \mathrm{mg} \mathrm{N}\right.$ g dry soil ${ }^{-1}, \mathrm{P}<0.0001$; Tables 3 and 7). On average, the $\mathrm{N}$ content of the LR subplots was $73 \%$ of the $\mathrm{N}$ content of the CTRL subplot. The average proportion of the $\mathrm{N}$ content in the LR subplot compared to the CTRL subplot in the 4.4-year manipulation plots (1-4) was $66 \%$, while the proportion of $\mathrm{N}$ content in the LR subplot was $76 \%$ of the CTRL subplot in the 2-year manipulation plots (5-12). The relative difference in soil $\mathrm{N}$ content did not correlate significantly with the CTRL soil C content (Fig. 2c).

The belowground total $\mathrm{N}$ stock, soil $\mathrm{N}$ stock $(0-5 \mathrm{~cm}$ depth), and $\mathrm{C}: \mathrm{N}$ ratio were also significantly lower in the LR subplots than in the CTRL subplots $(\mathrm{P}<0.0001$; Tables 3 and 7). Comparing the LR and CTRL within each plot, the difference was significant in 3 of the 12 plots for belowground total $\mathrm{N}$ stock and soil $\mathrm{N}$ stock, significant in 6 plots for soil $\mathrm{N}$ content and not significant in any plots for the $\mathrm{C}$ : $\mathrm{N}$ ratio (Table 7).

The soil $\mathrm{N}$ properties did not correlate significantly with forest floor $\mathrm{C}$ stocks other than between the soil $\mathrm{N}$ content and the understory leaf litter $\mathrm{C}$ stock (Table 2a). The soil C:N ratio notably correlated with the F-layer $\mathrm{C}$ stock (P $<0.001$; Table 2a, Fig. 3a) and positively correlated with the belowground properties, but no relationship was observed with the forest floor $\mathrm{C}$ stocks and those in coarse roots, and a negative relationship was noted between forest floor $\mathrm{C}$ and bulk density (Table $2 \mathrm{~b}$ ). The CTRL soil C:N ratio also correlated with the residual ratio of soil $\mathrm{C}$ content, i.e. the ratio of the LR to CTRL soil C content (Fig. 3b).

\section{Discussion}

\section{The annual litter supply and standing floor litter}

The annual leaf-litter $\mathrm{C}$ supply ranged from 1.9 to 4.5 $\mathrm{Mg} \mathrm{C} \mathrm{ha}{ }^{-1}$ in study sites with ca. $1500 \mathrm{~mm}$ of annual precip- 
Table 5. Soil carbon (C) content and stock in the litter removal (LR) and control (CTRL) experimental subplots

\begin{tabular}{cccccc}
\hline \hline & \multicolumn{2}{c}{ C content $\left[\mathrm{mg} \mathrm{C}\right.$ g dry soil $\left.{ }^{-1}\right]$} & \multicolumn{3}{c}{ Soil C stock $(0-5 \mathrm{~cm})\left[\mathrm{Mg} \mathrm{C} \mathrm{ha}^{-1}\right]$} \\
Plot & LR & CTRL & LR, depth-basis & LR, mass-basis & CTRL \\
\hline 1 & $7.2 \pm 1.0^{*}$ & $12.2 \pm 5.7$ & $5.7 \pm 0.7$ & $4.8 \pm 0.6 *$ & $8.2 \pm 1.8$ \\
2 & $4.8 \pm 0.3$ & $8.2 \pm 3.6$ & $3.6 \pm 0.2$ & $3.1 \pm 0.2$ & $5.3 \pm 0.2$ \\
3 & $7.4 \pm 0.4 *$ & $14.3 \pm 5.7$ & $5.7 \pm 0.3 *$ & $4.9 \pm 0.3 *$ & $9.4 \pm 1.4$ \\
4 & $7.3 \pm 0.7$ & $10.6 \pm 5.6$ & $5.6 \pm 0.4$ & $4.8 \pm 0.4$ & $6.9 \pm 0.5$ \\
5 & $7.7 \pm 1.9 *$ & $15.8 \pm 5.5$ & $5.5 \pm 1.3 *$ & $4.6 \pm 1.1 *$ & $9.5 \pm 0.3$ \\
6 & $8.3 \pm 1.1$ & $11.8 \pm 5.9$ & $5.9 \pm 0.7$ & $5.6 \pm 0.6$ & $7.9 \pm 0.3$ \\
7 & $11.0 \pm 0.8 *$ & $16.1 \pm 7.7$ & $7.7 \pm 0.3$ & $6.3 \pm 0.2 *$ & $9.3 \pm 1.0$ \\
8 & $10.5 \pm 0.7 *$ & $16.8 \pm 7.5$ & $7.5 \pm 0.8$ & $6.1 \pm 0.6 *$ & $9.8 \pm 0.4$ \\
9 & $5.9 \pm 0.7$ & $9.3 \pm 4.3$ & $4.3 \pm 0.6$ & $4.2 \pm 0.6$ & $6.6 \pm 1.0$ \\
10 & $24.7 \pm 2.7$ & $28.5 \pm 15.5$ & $15.5 \pm 0.7 *$ & $10.8 \pm 0.5$ & $12.6 \pm 1.3$ \\
11 & $11.2 \pm 0.7$ & $14.4 \pm 8.5$ & $8.5 \pm 0.3$ & $7.5 \pm 0.3$ & $9.7 \pm 1.2$ \\
12 & $15.9 \pm 1.6$ & $17.2 \pm 11.8$ & $11.8 \pm 1.0$ & $9.7 \pm 0.8$ & $10.5 \pm 0.2$ \\
Total & $10.2 \pm 5.5$ & $14.6 \pm 5.3$ & $7.3 \pm 3.3$ & $6.0 \pm 2.3$ & $8.8 \pm 2.1$ \\
\hline
\end{tabular}

Mean $\pm \mathrm{SD}, \mathrm{n}=3$. Asterisk $(*)$ indicates a significant difference between the LR and CTRL subplots within a plot. Mass-basis soil C stock in the LR was compared with the CTRL.

Table 6. Belowground carbon (C) stock of the surface-soil layer $(0-5 \mathrm{~cm})$ in the litter removal (LR) and control (CTRL) subplots

\begin{tabular}{|c|c|c|c|c|c|c|c|c|}
\hline \multirow[b]{2}{*}{ Plot } & \multicolumn{2}{|c|}{$\begin{array}{c}\text { Belowground total } \\
{\left[\mathrm{Mg} \mathrm{C} \mathrm{ha}^{-1}\right]}\end{array}$} & \multicolumn{2}{|c|}{$\begin{array}{l}\text { Coarse roots }(>2 \mathrm{~mm}) \\
{\left[\mathrm{Mg} \mathrm{C} \mathrm{ha}^{-1}\right]}\end{array}$} & \multicolumn{2}{|c|}{$\begin{array}{l}\text { Fine roots }(<2 \mathrm{~mm}) \\
\qquad\left[\mathrm{Mg} \mathrm{C} \mathrm{ha}^{-1}\right]\end{array}$} & \multicolumn{2}{|c|}{$\begin{array}{c}\text { Organic particles } \\
{\left[\mathrm{Mg} \mathrm{C} \mathrm{ha}^{-1}\right]}\end{array}$} \\
\hline & LR & CNTL & LR & CNTL & LR & CNTL & LR & CNTL \\
\hline 1 & $5.4 \pm 0.5$ & $10.1 \pm 2.9$ & $0.1 \pm 0.3$ & $0.6 \pm 1.1$ & $0.4 \pm 0.2$ & $0.7 \pm 0.1$ & $0.1 \pm 0.0$ & $0.6 \pm 0.2$ \\
\hline 2 & $3.6 \pm 0.3 *$ & $9.8 \pm 3.4$ & $0.0 \pm 0.0$ & $3.1 \pm 3.3$ & $0.5 \pm 0.4$ & $1.0 \pm 0.2$ & $0.1 \pm 0.1$ & $0.5 \pm 0.4$ \\
\hline 3 & $5.6 \pm 0.6$ & $10.9 \pm 1.4$ & $0.2 \pm 0.4$ & $0.2 \pm 0.4$ & $0.3 \pm 0.1$ & $0.5 \pm 0.2$ & $0.2 \pm 0.2$ & $0.8 \pm 0.5$ \\
\hline 4 & $5.5 \pm 0.3$ & $8.1 \pm 0.7$ & $0.2 \pm 0.2$ & $0.0 \pm 0.0$ & $0.3 \pm 0.0$ & $0.4 \pm 0.1$ & $0.2 \pm 0.3$ & $0.8 \pm 0.3$ \\
\hline 5 & $5.7 \pm 1.0 *$ & $11.8 \pm 0.8$ & $0.4 \pm 0.7$ & $0.9 \pm 0.9$ & $0.6 \pm 0.3$ & $1.3 \pm 0.2$ & $0.1 \pm 0.1$ & $0.2 \pm 0.1$ \\
\hline 6 & $7.3 \pm 1.5$ & $9.5 \pm 0.1$ & $1.0 \pm 1.0$ & $0.6 \pm 0.3$ & $0.6 \pm 0.2$ & $0.5 \pm 0.4$ & $0.2 \pm 0.2$ & $0.5 \pm 0.1$ \\
\hline 7 & $7.9 \pm 0.3$ & $11.0 \pm 0.7$ & $0.4 \pm 0.4$ & $0.2 \pm 0.3$ & $0.8 \pm 0.2$ & $1.0 \pm 0.2$ & $0.4 \pm 0.6$ & $0.5 \pm 0.3$ \\
\hline 8 & $10.0 \pm 3.9$ & $11.6 \pm 0.3$ & $2.9 \pm 3.7$ & $0.3 \pm 0.2$ & $0.7 \pm 0.2$ & $0.9 \pm 0.1$ & $0.3 \pm 0.3$ & $0.6 \pm 0.1$ \\
\hline 9 & $4.7 \pm 0.5$ & $7.1 \pm 0.8$ & $0.1 \pm 0.2$ & $0.0 \pm 0.0$ & $0.4 \pm 0.2$ & $0.4 \pm 0.1$ & $0.0 \pm 0.0$ & $0.2 \pm 0.1$ \\
\hline 10 & $14.5 \pm 1.8$ & $17.3 \pm 2.4$ & $0.4 \pm 0.6$ & $1.7 \pm 0.8$ & $1.0 \pm 0.2$ & $1.6 \pm 0.4$ & $2.4 \pm 1.4$ & $1.4 \pm 0.9$ \\
\hline 11 & $9.0 \pm 0.7$ & $11.6 \pm 1.5$ & $0.0 \pm 0.1$ & $0.5 \pm 0.4$ & $1.2 \pm 0.0$ & $1.1 \pm 0.5$ & $0.2 \pm 0.2$ & $0.3 \pm 0.1$ \\
\hline 12 & $10.7 \pm 0.8$ & $12.6 \pm 1.3$ & $0.2 \pm 0.2$ & $0.7 \pm 0.9$ & $0.5 \pm 0.7$ & $1.2 \pm 0.1$ & $0.3 \pm 0.1$ & $0.2 \pm 0.2$ \\
\hline Total & $7.5 \pm 3.2$ & $11.0 \pm 2.6$ & $0.5 \pm 0.8$ & $0.7 \pm 0.9$ & $0.6 \pm 0.3$ & $0.9 \pm 0.4$ & $0.4 \pm 0.7$ & $0.5 \pm 0.4$ \\
\hline
\end{tabular}

Mean $\pm \mathrm{SD}, \mathrm{n}=3$. Asterisk $(*)$ indicates a significant difference between the LR and CTRL subplots within a plot. Belowground total $\mathrm{C}$ stock indicates the sum of $\mathrm{C}$ stocks in mineral soils, coarse root, fine root, and organic particles. Mass-basis soil C stock is used for the LR, and see Table 5 for soil C stock.

itation and a distinct dry season, corresponding to litterfall of 380-900 $\mathrm{g} \mathrm{m}^{-2}$ (Appendix 3). When compared with other seasonal tropical forests with a distinctive dry season, a similar range of annual litterfall was found in deciduous and evergreen forests with ca. 1.5 times the precipitation in India $\left(568-865 \mathrm{~g} \mathrm{~m}^{-2}, 2338 \mathrm{~mm}\right)^{44}$ and ca. 1.4 times the precipitation in the dry evergreen forests of northern Thailand (688 $\mathrm{g}$ $\left.\mathrm{m}^{-2}, 2084 \mathrm{~mm}\right)^{12}$. Moreover, in the case of stands with similar precipitation displaying weak bimodal rainfall distribution, leaf-litter production near to, or less than, the lower end of our study sites was found in the sub-Mediterranean mixed with conifer and beech forest $\left(400 \mathrm{~g} \mathrm{~m}^{-2}, 1440 \mathrm{~mm}\right)^{18}$ and in the Colombian mountain rain forests $\left(282 \mathrm{~g} \mathrm{~m}^{-2}\right.$, $1453 \mathrm{~mm})^{55}$. Accordingly, Cambodian lowland dry evergreen forests likely produce more leaf litter than expected based on the precipitation, even though similar litter production has been observed in areas with less precipitation, for example, subtropical semiarid forests (330-810 $\mathrm{g} \mathrm{m}^{-2}, 725$ $\mathrm{mm})^{15}$ and dry evergreen forests $\left(343-960 \mathrm{~g} \mathrm{~m}^{-2}, 1040-1359\right.$ $\mathrm{mm})^{37}$, both located in India.

In general, decomposition rates are proportional to precipitation $^{36}$ or surface-soil moisture ${ }^{33}$. Given a larger litter supply than expected from the precipitation rates, the forest floors are expected to be in equilibrium with larger $\mathrm{C}$ stocks. 
Table 7. Belowground total (organic + inorganic) nitrogen $(\mathrm{N})$ stock, surface-soil $\mathbf{N}$ content $(0-5 \mathrm{~cm}$, depth-basis), and $C: N$ ratio in the litter removal (LR) and control (CTRL) experimental subplots

\begin{tabular}{|c|c|c|c|c|c|c|c|c|}
\hline \multirow[b]{2}{*}{ Plot } & \multicolumn{2}{|c|}{$\begin{array}{l}\text { Belowground total } \\
\qquad\left[\mathrm{Mg} \mathrm{N} \mathrm{ha}^{-1}\right]\end{array}$} & \multicolumn{2}{|c|}{$\begin{array}{c}\text { Soil N stock }(0-5 \mathrm{~cm}) \\
{\left[\mathrm{Mg} \mathrm{N} \mathrm{ha}^{-1}\right]}\end{array}$} & \multicolumn{2}{|c|}{$\begin{array}{c}\mathrm{N} \text { content } \\
{\left[\mathrm{mg} \mathrm{N} \text { g dry soil }{ }^{-1}\right]}\end{array}$} & \multicolumn{2}{|c|}{$\mathrm{C}: \mathrm{N}$ ratio } \\
\hline & LR & CTRL & LR & CTRL & LR & CTRL & LR & CTRL \\
\hline 1 & $0.39 \pm 0.06 *$ & $0.54 \pm 2.40$ & $0.38 \pm 0.06$ & $0.50 \pm 0.08$ & $0.48 \pm 0.06 *$ & $0.74 \pm 0.13$ & $15.2 \pm 3.3$ & $16.3 \pm 1.1$ \\
\hline 2 & $0.31 \pm 0.01$ & $0.44 \pm 2.00$ & $0.30 \pm 0.01$ & $0.36 \pm 0.03$ & $0.40 \pm 0.02$ & $0.56 \pm 0.02$ & $12.2 \pm 0.3$ & $14.7 \pm 0.6$ \\
\hline 3 & $0.43 \pm 0.02 *$ & $0.65 \pm 2.70$ & $0.42 \pm 0.02 *$ & $0.62 \pm 0.08$ & $0.54 \pm 0.02 *$ & $0.94 \pm 0.11$ & $13.7 \pm 0.3$ & $15.3 \pm 0.5$ \\
\hline 4 & $0.41 \pm 0.02$ & $0.51 \pm 2.60$ & $0.40 \pm 0.02$ & $0.48 \pm 0.03$ & $0.52 \pm 0.04 *$ & $0.74 \pm 0.10$ & $14.1 \pm 0.3$ & $14.3 \pm 0.2$ \\
\hline 5 & $0.42 \pm 0.06 *$ & $0.66 \pm 2.75$ & $0.40 \pm 0.07 *$ & $0.61 \pm 0.02$ & $0.55 \pm 0.09 *$ & $1.02 \pm 0.04$ & $13.8 \pm 1.0$ & $15.5 \pm 0.4$ \\
\hline 6 & $0.44 \pm 0.05$ & $0.52 \pm 2.85$ & $0.41 \pm 0.04$ & $0.49 \pm 0.01$ & $0.57 \pm 0.06$ & $0.73 \pm 0.02$ & $14.4 \pm 0.3$ & $16.2 \pm 0.6$ \\
\hline 7 & $0.57 \pm 0.02$ & $0.59 \pm 3.80$ & $0.54 \pm 0.02$ & $0.55 \pm 0.05$ & $0.76 \pm 0.04$ & $0.95 \pm 0.08$ & $14.5 \pm 0.7$ & $16.9 \pm 0.5$ \\
\hline 8 & $0.54 \pm 0.05$ & $0.62 \pm 3.40$ & $0.49 \pm 0.05$ & $0.58 \pm 0.02$ & $0.68 \pm 0.03 *$ & $1.00 \pm 0.05$ & $15.6 \pm 0.3$ & $16.8 \pm 0.3$ \\
\hline 9 & $0.33 \pm 0.04$ & $0.47 \pm 2.15$ & $0.32 \pm 0.04 *$ & $0.46 \pm 0.03$ & $0.43 \pm 0.05 *$ & $0.65 \pm 0.04$ & $13.7 \pm 0.3$ & $14.3 \pm 1.2$ \\
\hline 10 & $0.72 \pm 0.06$ & $0.61 \pm 5.05$ & $0.64 \pm 0.04$ & $0.52 \pm 0.05$ & $1.01 \pm 0.12$ & $1.17 \pm 0.01$ & $24.5 \pm 0.4$ & $24.3 \pm 0.4$ \\
\hline 11 & $0.54 \pm 0.03$ & $0.58 \pm 3.35$ & $0.51 \pm 0.02$ & $0.54 \pm 0.07$ & $0.67 \pm 0.03$ & $0.81 \pm 0.08$ & $16.8 \pm 0.2$ & $17.9 \pm 0.1$ \\
\hline 12 & $0.57 \pm 0.04$ & $0.53 \pm 3.70$ & $0.55 \pm 0.04$ & $0.49 \pm 0.01$ & $0.74 \pm 0.07$ & $0.79 \pm 0.03$ & $21.6 \pm 0.2$ & $21.7 \pm 0.1$ \\
\hline Total & $0.47 \pm 0.12$ & $0.56 \pm 0.07$ & $0.44 \pm 0.10$ & $0.52 \pm 0.07$ & $0.61 \pm 0.17$ & $0.84 \pm 0.18$ & $15.8 \pm 3.6$ & $17.0 \pm 3.1$ \\
\hline
\end{tabular}

Mean $\pm \mathrm{SD}, \mathrm{n}=3$. Asterisk $(*)$ indicates a significant difference between the LR and CTRL subplots. Belowground total $\mathrm{N}$ stock indicates the sum of $\mathrm{N}$ stocks in mineral soils, coarse root, fine root, and organic particles.
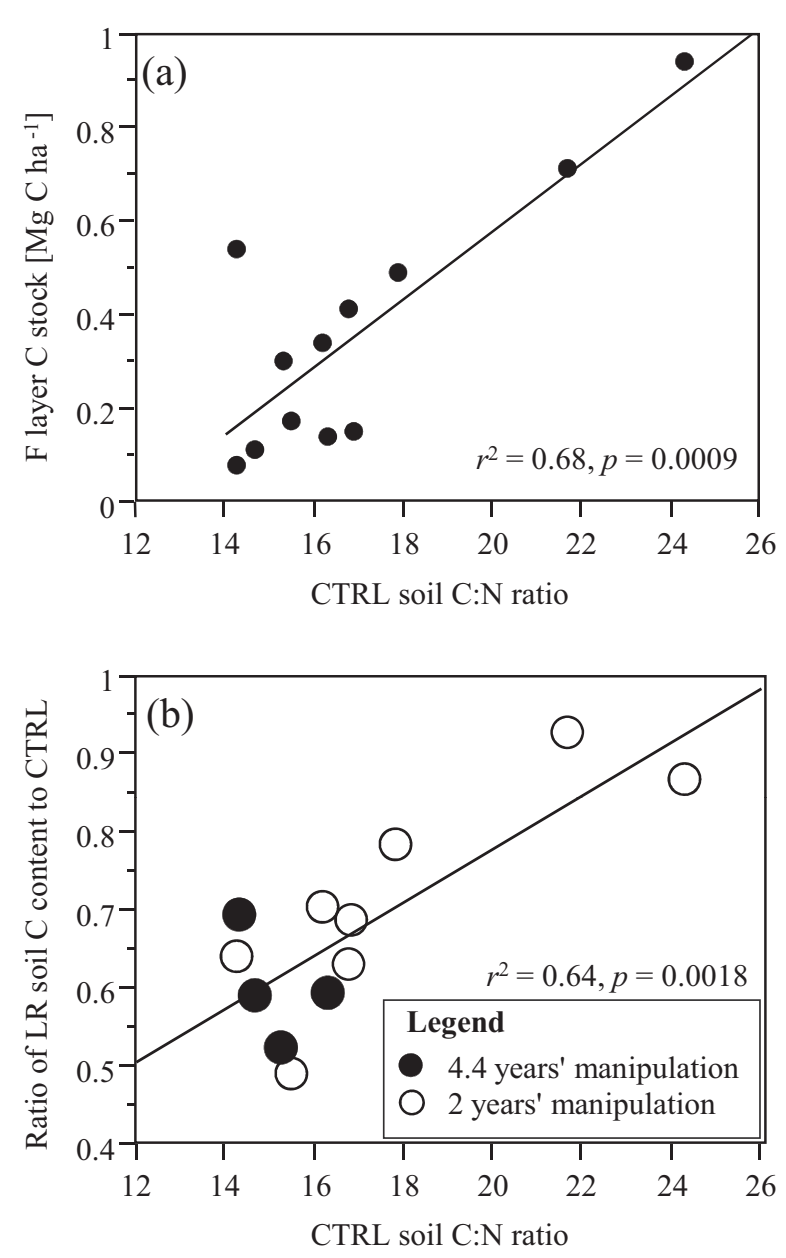

Fig. 3. Relationships between the control (CTRL) soil $\mathrm{C}: \mathrm{N}$ ratio, (a) the $\mathrm{C}$ stock in the $\mathrm{F}$-layer, and (b) the ratio of the litter removal (LR) to CTRL soil C content
Increased litterfall can actually drive net soil $\mathrm{C}$ losses to the atmosphere ${ }^{41,43}$, while standing leaf litter reflects the balance of litterfall and decomposition ${ }^{17}$. Remaining $\mathrm{C}$ stocks in Land F-layers corresponded to $29 \pm 10$ and $11 \pm 9 \%$ of the annual leaf litter supply respectively, suggesting that ca. $60 \%$ of leaf litter is decomposed or incorporated to soil within a year, or within 6 months under discrete wet-dry seasonality.

Rapid decomposition rates in forest floor litter have been reported in Thailand (22-60\% per 6 months $)^{45}$. In addition, a considerable variation in decomposition rates among plots was suggested here by the absence of a correlation between the L-layer C stock and the F-layer C stock (Table 2a). Still, we have not determined the actual status of the $\mathrm{C}$ cycle in forest studies, and a lack of information on litter decomposition dynamics, particularly in Cambodian forest ecosystems, suggests the need for further investigation.

\section{Soil properties within the context of forest floor litter conditions}

Variation in leaf-litter amounts may affect leaf-litter nutrient cycling and forest productivity ${ }^{59}$. Accordingly, larger belowground $\mathrm{C}$ and $\mathrm{N}$ properties (content and stock) are expected under larger forest floor stocks, given less spatial variation in decomposition rates. However, our data did not support this expectation. Belowground $\mathrm{C}$ and $\mathrm{N}$ properties did not correlate with either the L-layer $\mathrm{C}$ stock or the total forest floor C stock (Table 2a). Here the L-layer C stock likely indicates the amount of $\mathrm{C}$ supply that is quickly decomposed, whereas the total forest floor $\mathrm{C}$ stock indicates the potential $\mathrm{C}$ supply, including a considerable contribution of spatially heterogeneous branch distribution to the total 
forest floor $\mathrm{C}$ stock (47\% of the total; Table 1). These results suggest that the quantity of $\mathrm{C}(\mathrm{N})$ supply cannot sufficiently explain the variation in belowground $\mathrm{C}$ and $\mathrm{N}$ properties, although they did explain the reduced variation in the total litter supply among plots (Appendix 1).

Rather, it was the F-layer $\mathrm{C}$ stock that correlated positively with soil $\mathrm{C}$ contents, soil $\mathrm{C}$ stocks, and belowground total C stocks (Table 2a), and the F-layer C stock in particular correlated strongly with the soil $\mathrm{C}: \mathrm{N}$ ratio (Fig. $3 \mathrm{a}$ ). These results suggest that a high soil $\mathrm{C}$ storage potential is expected for a forest floor with high $\mathrm{C}$ stocks in the F-layer, which is likely characterized by slow decomposition as indicated by the reduction in soil $\mathrm{C}$ depletion found in the larger $\mathrm{C}: \mathrm{N}$ ratio in soil (Fig. $3 \mathrm{~b}$ ). Together, the $\mathrm{C}$ cycle is likely governed by decomposition rates rather than the quantity of litter supply.

The soil water content strongly influences decomposition rates, like surface temperature, while higher soil moisture generally drives higher decomposition rates in the tropics $^{33}$. Despite this, we found that the gravimetric and volumetric soil water contents were positively and strongly correlated with soil $\mathrm{C}$ properties, as well as soil $\mathrm{N}$ properties, although to a lesser degree (Table $2 b$ ). In addition, the gravimetric soil water content correlated positively with the F-layer $\mathrm{C}$ stock $(\mathrm{P}<0.05)$, while displaying negative trends with the L-layer $\mathrm{C}$ stock, and the total forest floor $\mathrm{C}$ stock ( $\mathrm{P}<0.05$ in all cases; Table 2a). Together, $\mathrm{C}$ - and N-rich soils were found under a forest floor comprising a poor Llayer and a rich F-layer with a high moisture condition; however, we were unable to establish a cause-and-effect relationship among these factors.

\section{Influence of litter supply limitation on physicochemical soil properties}

Litter manipulation can affect ecosystem $\mathrm{C}$ turnover, soil nutrients, and physical soil properties, such as water availability and the bulk density of the upper soil layers ${ }^{40}$. Previous litter manipulation studies have consistently shown that litter removal has less of an effect than litter addition on soil properties ${ }^{22,41,42,59}$. In particular, short-term litterremoval manipulation experiments conducted mainly in temperate forests have shown few significant changes in soil properties $^{40}$. However, relatively rapid changes have been reported in wet tropical forests, where significant changes were detected after only 1-2 years of treatment ${ }^{22,54}$. In this study, the 4.4- and 2-year litter removal manipulations both significantly influenced the physicochemical soil properties that we measured (Table 3 ). These results suggest that seasonal tropical forests with a discrete wet-dry fluctuation respond to litter removal similarly to wet tropical forests rather than temperate forests.

(1) Bulk density and soil water contents

Litter forms a layer on the mineral soil surface and effectively protects against soil compaction ${ }^{25,26,35,40}$. In the absence of a shock-absorbing litter layer, the impact of raindrops causes an increase in bulk density, indicating soil compaction $^{1}$, whereby the kinetic energy of raindrops causes the destruction of soil aggregates, the separation of fine particles $^{40}$, and the re-accumulation of erosive sediments displaying higher bulk density ${ }^{31}$. Despite the importance of forest litter, few studies have quantified changes to soil physical properties following litter manipulation ${ }^{40}$. This study clearly displayed the significant effects of litter removal on bulk density and gravimetric and volumetric soil water contents after a relatively short manipulation (Table 3). However, the lack of a relationship between forest floor $\mathrm{C}$ stock properties and bulk density suggested that natural litter cover provides adequate protection for the soil (Table 2a).

Greater increases in bulk density were found in plots with a smaller CTRL bulk density (Fig. 2a), suggesting that greater soil compaction occurs in stands with a smaller initial bulk density, as found in previous studies ${ }^{1,35}$. Consequently, the LR bulk density soared $\left(>1.40 \mathrm{mg} \mathrm{m}^{-3}\right.$; Table 4), reaching a degree that prevented further compaction by heavy forest machinery ${ }^{1,35}$. Moreover, the degree of soil compaction did not differ between the litter-removal experiments lasting more than 4 years (plots $1-4$ ) or 2 years (plots 5-12; Fig. 2a), which suggests that litter removal rapidly results in "ultimate" high soil compaction in less than 2 years.

Soil compaction, which decreases soil porosity, aeration, and infiltration capacity, consequently prevents root growth $^{21}$. In general, the upper bulk density limit for root penetration is ca. 1.4 to $1.6 \mathrm{Mg} \mathrm{m}^{-3}$ for fine-textured soils like the study sites, but higher at $1.75 \mathrm{Mg} \mathrm{m}^{-3}$ for coarsertextured soils ${ }^{35}$. According to this criteria, LR soils become sufficiently compacted to prevent root growth, which supported a significantly lower fine root $\mathrm{C}$ stock in the LR plots than in the CTRL plots (Tables 3 and 6). The threshold of soil compaction that causes plant decline was reported as a surface bulk density of $>1.00 \mathrm{Mg} \mathrm{m}^{-3}$ for Japanese cedar in flat alluvial plains ${ }^{14}$. However, no such threshold was reported for tropical forest trees.

Contrary to the quick response of most soil properties to litter supply reduction, density recovery was generally slow with a time span of 10-12 years ${ }^{24,32,35}$. Once hydrological conditions are altered ${ }^{21,25,26}$, and soil arthropod habitats are destroyed ${ }^{17}$, density recovery is seriously hindered. Moreover, fine and coarse roots are the primary source of belowground $\mathrm{C}$ and influence the physical, chemical, and biological properties of soil ${ }^{15}$. Once soil compaction proceeds to a level preventing root penetration, density recovery may be delayed compared with the case of minor compaction that does not affect root growth. Significant negative correlations were found here between the bulk den- 
sity and the amount of fine roots (Table 2b), indicating that 2 years of limited litter supply may result in severe soil compaction from which recovery is difficult. This is despite the fact that the growth of coarse roots seemed unaffected by soil compaction (Table $2 b$ ).

Changes in soil water content may be quite drastic following litter-removal manipulation ${ }^{40}$. In this study, gravimetric soil water content was clearly lower in LR than CTRL plots (Tables 3 and 4), while the volumetric soil water content was slightly higher in the LR than CTRL plots. This result implied that the increase in bulk density counterbalanced the decrease in gravimetric soil water content. Still, positive relationships were observed between fine root $\mathrm{C}$ stock and the gravimetric soil water content (Table 2b), suggesting that lower soil moisture was at least partially responsible for reductions in fine root biomass under litter supply limitation, consistent with previous studies $^{22}$. The forest degradation that usually accompanies gap generation helped limit the litter supply in this study. Accordingly, when evaluating the influence of forest degradation on the soil moisture condition, the influence of gap size on soil moisture regimes should be considered ${ }^{23}$.

(2) C content and belowground C stocks

Very sensitive changes in soil $\mathrm{C}$ cycling caused by litter manipulations were previously reported in wet tropical forests $^{22,41}$. The 2 years of litter-removal manipulation from the forest floor decreased the surface-soil C contents to $74 \%$ of the control value in a Costa Rican tropical rain forest ${ }^{22}$. This study conducted in a seasonal tropical forest also found significant and similar degrees of soil $\mathrm{C}$ content reduction (to $67 \%$ of the CTRL on average) after the 4.4- and 2-year manipulations (Tables 3 and 5). The 4.4-year manipulation plots showed a greater soil $\mathrm{C}$ content reduction (to $60 \%$ of the CTRL) than the 2-year manipulation plots (71\%), indicating that the influence of litter supply limitation on the $\mathrm{C}$ stock lasts over 2 years, in contrast to the bulk density that rapidly reached its upper limit (Fig. 2a).

Large soil $\mathrm{C}$ pools and ideal climatic conditions combine to promote changes in $\mathrm{C}$ cycling in tropical forests ${ }^{22}$. Elsewhere, forests with a larger litterfall supply reportedly have the potential to drive net $\mathrm{C} \operatorname{losses}^{41}$. The relative difference in soil $\mathrm{C}$ content, however, did not correlate significantly with the CTRL soil $\mathrm{C}$ content (linear regression analysis; Fig. 2b). These results clearly indicate that C-rich soils did not lose a relatively greater proportion of $\mathrm{C}$ following litter removal than $\mathrm{C}$-poor soils, in contrast to the greater soil compaction that occurred in stands with a smaller initial bulk density.

In recent years $\mathrm{C}$ sequestration has gained public attention as an important forest ecosystem service. In REDD and REDD-plus schemes ${ }^{11}$, anthropogenic changes in forest $\mathrm{C}$ stocks ${ }^{27}$ must be quantified. Soil $\mathrm{C}$ stocks comprise a large pool in forests and non-forest terrestrial ecosystems ${ }^{7}$. In
Cambodian evergreen forests, soil $\mathrm{C}$ contributes the second largest C pool (20.3\%) within the total forest C stock (280.5 $\left.\mathrm{Mg} \mathrm{ha}^{-1}\right)^{53}$. Mass-based soil C stores were lower in LR than CTRL plots (67\% of the CTRL; Tables 3 and 5), suggesting considerable forest $\mathrm{C}$ stock reduction under limited litter supply, particularly when accompanied by forest degradation. Compared to the considerable depletion in the massbased soil C stock, depth-based soil C stock measurements displayed more conservative results as a customary approach (LR was $80 \%$ of the CTRL). This was because the effect of the decrease in $\mathrm{C}$ content was partially canceled out by the increase in bulk density when calculating the depth-based soil C stock.

Litter-removal effects in non-soil belowground $\mathrm{C}$ stocks were relatively unclear (Tables 3 and 6), suggesting a relatively small impact on the total belowground $\mathrm{C}$ stocks following a reduction in root biomass and organic matter under litter supply limitation, despite the fact that non-soil belowground $\mathrm{C}$ stocks contributed (19\% in the CTRL) and correlated with the total belowground $\mathrm{C}$ stocks (except for coarse roots; Table $2 \mathrm{~b}$ ). This result is consistent with the lack of positive correlation between forest floor $\mathrm{C}$ stock properties and non-soil belowground $\mathrm{C}$ stocks (Table 2a). Note that fine root biomass decreased, correlating positively with soil compaction and reductions in soil moisture caused by litter removal treatments (Tables 2b, 3 and 6), which suggests a long-lasting influence on non-soil belowground $\mathrm{C}$ sources. In addition, our findings may underestimate the influence of fine roots. Fine root biomass decreased during the dry season in the subtropical semiarid region ${ }^{15}$. We conducted core sampling at the end of the dry season when root biomass was likely at its minimum. Accordingly, the difference in fine roots between the CTRL and LR plots may be larger during the wet season. Less clear is the role of roots in mediating or accelerating soil $\mathrm{C}$ response to changes in litter inputs ${ }^{22}$.

(3) Belowground N status

Litterfall is an important pathway for $\mathrm{N}$, rather than phosphorus, in lowland tropical forests ${ }^{42,57}$. However, we rarely found belowground $\mathrm{N}$-rich properties under larger forest floor litter stocks (Table 2a). In addition, the amount of understory litter, which was the only factor to correlate significantly with soil $\mathrm{N}$ content, seems unable to quantitatively explain the variation in soil $\mathrm{N}$ content because it was a small proportion of the total forest floor (Tables 1, 2b). These results suggest that organic $\mathrm{N}$ supply from the litter layer is not a critical factor controlling the soil $\mathrm{N}$ content.

In contrast to litter layer properties, a significant correlation was observed between the amount of fine root mass and the soil $\mathrm{N}$ content (Table $2 \mathrm{~b}$ ), which implies two possible, but different, interpretations. One is that larger fine root biomass is responsible for higher soil $\mathrm{N}$ content probably due to the contribution to soil $\mathrm{N}$ supply via fine root detritus 
and exudates. Another is that higher N content is responsible for a larger amount of fine roots. Since this study provided only total $\mathrm{N}$ data, not inorganic $\mathrm{N}$, interpretation should be cautious. However, some dipterocarp seedlings enable access to organic nutrient sources via ectomycorrhizal associations ${ }^{5}$. Accordingly, the total $\mathrm{N}$ concentration potentially explains the fine root distribution ${ }^{22}$.

Given the N-limited conditions common in the tropics, the $\mathrm{N}$ cycle is expected to be less sensitive to litter manipulation compared to the $\mathrm{C}$ cycle ${ }^{22,59}$. Accordingly, less sensitive responses in soil $\mathrm{N}$ availability and in consequence, litter $\mathrm{N}$ concentration ${ }^{40}$ or forest productivity ${ }^{59}$, help establish a steady-state equilibrium among natural communities ${ }^{56}$.
Contrary to expectations, our litter-removal manipulation drove decreases in soil $\mathrm{N}$ contents and belowground $\mathrm{N}$ stocks as clearly as it affected C properties (Table 3). Plots displaying significant differences in the $\mathrm{N}$ content between CTRL and LR plots generally also displayed significant differences for the $\mathrm{C}$ content (Tables 5 and 7). Accordingly, similar depletion rates between $\mathrm{C}$ and $\mathrm{N}$ in soils were suggested in this study and the relatively conservative trends in the $\mathrm{C}: \mathrm{N}$ ratio between the CTRL and LR plots supported these findings (Tables 3 and 7).

$\mathrm{N}$-rich soils generally appear to lose a greater relative proportion of $\mathrm{N}$ following litter removal than $\mathrm{N}$-poor soils ${ }^{40}$. However, we did not find this trend (Fig. 2c). One possible

Appendix 1. Major tree species in litter-removal plots arranged by the amount of litter increase

\begin{tabular}{|c|c|c|c|}
\hline Plot & Species & Layer & Logging pressure \\
\hline \multirow[t]{8}{*}{$1-4$} & Dipterocarpus costatus C.F. Gaertn. & Overstory & High \\
\hline & Sindora siamensis Teysm. ex Miq. & Overstory & Medium \\
\hline & Anisoptera costata Korth & Overstory & High \\
\hline & Syzygium sp. & Understory-mid & Low \\
\hline & Alphonsea boniana Craib & Understory-mid & Low \\
\hline & Canthium sp. & Understory-low & Low \\
\hline & Chionanthus ramiflorus Roxb. & Understory-low & Low \\
\hline & Neolitsea siamensis Kosterm. & Understory-low & Low \\
\hline \multirow[t]{10}{*}{$5-8$} & Anisoptera costata & Overstory & High \\
\hline & Vatica cinerea King & Understory-mid & Low \\
\hline & Vatica odorata (Griff.) Symington var. odorata & Understory-mid & Low \\
\hline & Calophyllum tetrapetalum Roxb. & Understory-mid & Low \\
\hline & Dipterocarpus costatus & Overstory & High \\
\hline & Pelthophorum dasyrrhachis (Miq.) Kurz & Understory-mid & Low \\
\hline & Aporosa sp. & Understory-low & Low \\
\hline & Mangifera duppereana Pierre & Understory-mid & Low \\
\hline & Alphonsea boniana & Understory-mid & Low \\
\hline & Diospyros undulata Hiern & Understory-mid & Low \\
\hline \multirow[t]{4}{*}{9} & $\begin{array}{l}\text { Tristaniopsis burmanica (Griff.) Wils. \& Wat. var. } \\
\text { rufescens (Hance) J.Parn. \& NicLugh. }\end{array}$ & Understory-mid & Low \\
\hline & Myristica iners Blume & Overstory & Low \\
\hline & $\begin{array}{l}\text { Syzygium gratum (Wight) S.N. Mitra var. confertum } \\
\text { Chantar. \& J.Parn. }\end{array}$ & Understory-mid & Low \\
\hline & Bousigonia angustifolia Pierre ex Spire & Understory-low & Low \\
\hline \multirow[t]{4}{*}{10} & Irvingia malayana Oliv. ex Benn. & Overstory & Low \\
\hline & Alphonsea boniana & Understory-mid & Low \\
\hline & Aporosa villosa (Lind1.) Baill. & Understory-low & Low \\
\hline & Neolitsea siamensis & Understory-low & Low \\
\hline \multirow[t]{4}{*}{11} & Alphonsea boniana & Understory-mid & Low \\
\hline & Myristica iners & Overstory & Low \\
\hline & Syzygium siamense (Craib) Chant. \& Parn. & Understory-mid & Low \\
\hline & Tristaniopsis burmanica var. rufescens & Understory-mid & Low \\
\hline \multirow[t]{4}{*}{12} & Tristaniopsis burmanica var. rufescens & Understory-mid & Low \\
\hline & Calophyllum inophyllum $\mathrm{L}$. & Understory-mid & Low \\
\hline & Pternandra caerulescens Jack & Understory-low & Low \\
\hline & Garcinia oblongifolia Champ. ex Benth & Understory-low & Low \\
\hline
\end{tabular}


explanation would be that all our plots belonged to N-poor soils. In addition, compared to the regression analysis of 30 previous litter removal studies ${ }^{40}$, our plots displayed much more $\mathrm{N}$ depletion when standardized by the initial (CTRL) $\mathrm{N}$ concentration. Overall, the forest soil response to litterremoval manipulation was characterized by rapid decompo-

Appendix 2. Carbon (C) and nitrogen (N) contents in forest floor litter, roots, and belowground organic particles

\begin{tabular}{|c|c|c|c|c|c|c|c|}
\hline \multirow[b]{2}{*}{ Item } & \multirow{2}{*}{$\begin{array}{c}\text { Plot } \\
\text { Sample } \\
\text { collected }\end{array}$} & \multicolumn{2}{|c|}{$\begin{array}{l}\mathrm{C} \text { content } \\
{\left[\mathrm{mg} \mathrm{C} \mathrm{g}^{-1}\right]}\end{array}$} & \multicolumn{4}{|c|}{$\begin{array}{l}\mathrm{N} \text { content } \\
{\left[\mathrm{mg} \mathrm{N} \mathrm{g}^{-1}\right]}\end{array}$} \\
\hline & & Mean & $\mathrm{SD}$ & $\mathrm{n}$ & Mean & SD & $\mathrm{n}$ \\
\hline \multicolumn{8}{|l|}{ L-layer (fresh leaf litter) } \\
\hline \multicolumn{8}{|l|}{ Overstory species } \\
\hline Dipterocarpus costatus & $1-8$ & 509.3 & - & 1 & 9.5 & - & 1 \\
\hline Anisoptera costata & $1-8$ & 517.5 & - & 1 & 10.3 & - & 1 \\
\hline Sindora siamensis & $1-8$ & 519.5 & - & 1 & 8.2 & - & 1 \\
\hline Irvingia malayana & 9 & 467.6 & - & 1 & 7.3 & - & 1 \\
\hline Myristica iners & 10 & 568.8 & - & 1 & 9.7 & - & 1 \\
\hline \multicolumn{8}{|l|}{ Understory species } \\
\hline Syzygium sp. & 10 & 538.2 & - & 1 & 6.0 & - & 1 \\
\hline Tristaniopsis burmanica var. rufescens & 10,12 & 533.2 & - & 1 & 3.8 & - & 1 \\
\hline The other & $1-12$ & 506.8 & 17.7 & 12 & 9.6 & 1.41 & 12 \\
\hline F-layer & $1-12$ & 480.7 & 22.1 & 12 & 11.3 & 2.02 & 12 \\
\hline Branches & $1-12$ & 511.8 & 14.7 & 3 & 6.9 & 0.35 & 3 \\
\hline Reproductive organs & $1-12$ & 477.2 & - & 1 & 10.4 & - & 1 \\
\hline \multicolumn{8}{|l|}{ Belowground } \\
\hline Fine roots $<2 \mathrm{~mm}$ in diameter & $1-12$ & 457.3 & 32.6 & 6 & 10.6 & 1.55 & 6 \\
\hline Coarse roots $>2 \mathrm{~mm}$ in diameter & $1-12$ & 490.9 & 12.8 & 5 & 6.5 & 0.61 & 5 \\
\hline Organic matter in soil $>2 \mathrm{~mm}$ in diameter & $1-12$ & 378.8 & 35.8 & 6 & 7.8 & 1.28 & 6 \\
\hline
\end{tabular}

Appendix 3. Carbon (C) supply via fallen litter in the litter-removal (LR) subplots

\begin{tabular}{|c|c|c|c|c|c|c|c|}
\hline \multicolumn{8}{|c|}{ Annual mean $( \pm \mathrm{SD})\left[\mathrm{Mg} \mathrm{C}^{-1} \text { year }^{-1}\right]^{\#}$} \\
\hline \multirow[b]{2}{*}{ Plot } & \multicolumn{4}{|c|}{ Leaves } & \multirow[t]{2}{*}{ Branches $^{\dagger}$} & \multirow{2}{*}{$\begin{array}{l}\text { Repro- } \\
\text { ductive } \\
\text { organs }\end{array}$} & \multirow[t]{2}{*}{ Total $^{\dagger}$} \\
\hline & $\begin{array}{l}\text { Overstory- } \\
\text { logged }\end{array}$ & $\begin{array}{l}\text { Overstory- } \\
\text { unlogged }\end{array}$ & Understory & Total & & & \\
\hline $1-4$ & $2.1 \pm 0.2$ & - & $1.5 \pm 0.1$ & $3.2 \pm 0.2$ & $>0.2 \pm 0.2$ & $0.3 \pm 0.3$ & $>4.1 \pm 0.3$ \\
\hline $5-8$ & $1.3 \pm 0.0$ & - & $2.0 \pm 0.1$ & $3.7 \pm 0.2$ & $>0.3 \pm 0.0$ & $0.1 \pm 0.0$ & $>3.7 \pm 0.2$ \\
\hline 9 & $0.1 \pm 0.2$ & $2.7 \pm 1.5$ & $1.7 \pm 0.4$ & $4.5 \pm 1.0$ & $>0.1 \pm 0.1$ & $1.0 \pm 0.8$ & $>5.6 \pm 1.7$ \\
\hline 10 & - & $0.6 \pm 0.0$ & $2.8 \pm 0.3$ & $3.4 \pm 0.3$ & $>0.2 \pm 0.2$ & $0.0 \pm 0.1$ & $>3.6 \pm 0.6$ \\
\hline $11^{\dagger}$ & $>0 \pm 0$ & $>0.5 \pm 0.1$ & $>1.4 \pm 0.1$ & $>1.9 \pm 0.2$ & $>0 \pm 0$ & $>0.0 \pm 0.0$ & $>1.9 \pm 0.2$ \\
\hline 12 & - & $0.0 \pm 0.0$ & $3.3 \pm 0.1$ & $3.3 \pm 0.1$ & $>0.1 \pm 0.1$ & $0.0 \pm 0.0$ & $>3.4 \pm 0.0$ \\
\hline
\end{tabular}

Total during the litter removal experiment $\left[\mathrm{Mg} \mathrm{C} \mathrm{ha}^{-1}\right]$

\begin{tabular}{|c|c|c|c|c|c|c|c|c|}
\hline \multirow[b]{2}{*}{ Plot } & \multicolumn{4}{|c|}{ Leaves } & \multirow[t]{2}{*}{ Branches $^{\dagger}$} & \multirow{2}{*}{$\begin{array}{l}\text { Repro- } \\
\text { ductive } \\
\text { organs }\end{array}$} & \multirow[t]{2}{*}{ Total $^{\dagger}$} & \multirow{2}{*}{$\begin{array}{l}\text { Experi- } \\
\text { mental } \\
\text { period }\end{array}$} \\
\hline & $\begin{array}{c}\text { Overstory- } \\
\text { logged }\end{array}$ & $\begin{array}{c}\text { Overstory- } \\
\text { unlogged }\end{array}$ & Understory & Total & & & & \\
\hline $1-4$ & 9.8 & - & 6.8 & 16.7 & $>0.8$ & 1.6 & $>19.1$ & 4.4 \\
\hline $5-8$ & 2.5 & - & 3.9 & 6.5 & $>0.6$ & 0.2 & $>7.3$ & 2 \\
\hline 9 & 0.3 & 5.4 & 3.3 & 9.0 & $>0.2$ & 2.1 & $>11.3$ & 2 \\
\hline 10 & - & 1.2 & 5.7 & 6.9 & $>0.3$ & 0.1 & $>7.3$ & 2 \\
\hline $11^{\dagger}$ & $>0$ & $>0.9$ & $>2.8$ & $>3.7$ & $>0$ & $>0.0$ & $>3.7$ & 2 \\
\hline 12 & - & 0.0 & 6.6 & 6.6 & $>0.2$ & 0.0 & $>6.7$ & 2 \\
\hline
\end{tabular}

\# The annual average for plots 1-4 was calculated for 4 years from March 2005 to February 2009. The data for the first 5 months of the experiment were omitted from the average calculation.

$\dagger$ The amounts of branches for all subplots were underestimated because of mistreatment of the collected samples, and the values for plot 11 were also underestimated because one litter sample was missing (10-20 December, 2008). 
sition, possibly accelerated by a tropical climate and a low attenuation capacity for $\mathrm{N}$ retention.

\section{Conclusions and future remarks}

Collectively, our results suggest that seasonal tropical forest soil physicochemical soil properties are very sensitive to changes in litter inputs, much like wet tropical forests. We found a difference in response to litter manipulation between bulk density (when changes were rapid and reached the upper limits of soil compaction within 2 years) and soil $\mathrm{C}$ and $\mathrm{N}$ contents (when changes lasted over 2 years). Decomposition rates of soil-stored $\mathrm{C}$ and $\mathrm{N}$ seemed to vary considerably among plots, while $\mathrm{C}$ and $\mathrm{N}$ depletion rates were similar within each plot, suggesting less attenuation capacity for $\mathrm{N}$ retention despite $\mathrm{N}$-poor soils. These findings may provide insights to mediate the impacts of forest degradation, whereby moves to recover adequate litter supply, probably by understory trees occupying the gaps, are required as soon as possible, before the upper limit of soil compaction is reached.

This study also highlights the quantitative linkage between litter supply, standing floor litter, and soil C properties, indicating that the spatial variation in the $\mathrm{C}$ cycle is likely attributable to decomposition rates, rather than the quantity of litter supply. Less understood is the role of roots in minimizing soil compaction and $\mathrm{C}(\mathrm{N})$ response to changes in litter inputs, particularly in root growth changes with the concurrent alteration in soil moisture and nutrient availability. In this context, we illustrated the importance of a process-based understanding of physicochemical soil properties, soil degradation, and recovery following disturbance to determine whether a given human impact is within a forest's recoverable limits.

\section{Acknowledgments}

The authors are deeply indebted to the director of Forestry Administration at the Ministry of Agriculture, Forestry and Fisheries for permission to undertake field research and transport samples. We also thank Dr. J. F. Maxwell, CMU Herbarium, Chiang Mai, Thailand, for identifying specimens.

\section{References}

1. Ampoorter, E. et al. (2010) Assessing the effects of initial soil characteristics, machine mass and traffic intensity on forest soil compaction. For. Ecol. Manage., 260, 1664-1676.

2. Araki, M. et al. (2008) Seasonal fluctuation of groundwater in an evergreen forest, central Cambodia: experiments and two-dimensional numerical analysis. Paddy Water Environ., 6, 37-46.

3. Araki, M. \& Ito, E. (2009) Dry evergreen forests in central flat lowland areas of Cambodia and site environment conditions. Jpn. J. For. Environ., 51, 1-11 [in Japanese with English summary].

4. Bond-Lamberty, B. \& Thomson, A. (2010) Temperatureassociated increases in the global soil respiration record. Nature, 464, 579-581.

5. Brearley, F. Q. et al. (2003) Nutrients obtained from leaf litter can improve the growth of dipterocarp seedlings. New Phytol., 160, 101-110.

6. Chann, S. et al. (2011) Interannual variation in the evapotranspiration of an evergreen forest in Kampong Thom, central Cambodia. In Proceedings of International Workshop on Forest Research in Cambodia, November 2011, Phnom Penh, Cambodia, 21-24.

7. Dixon, R. K. et al. (1994) Carbon pools and flux of global forest ecosystems. Science, 263, 185.

8. FAO (2010) Global forest resources assessment 2010. FAO, Rome. http://www.fao.org/forestry/fra/fra2010/en/.

9. FAO (2011) State of the World's Forests 2011. FAO, Rome. http://www.fao.org/docrep/013/i2000e/i2000e00.htm.

10. Forestry Administration et al. (2008) Cambodia forest cover, Forest cover map change 2002-2006. Forestry administration, Kingdom of Cambodia.

11. GOFC-GOLD (2009) Reducing greenhouse gas emissions from deforestation and degradation in developing countries: a sourcebook of methods and procedures for monitoring, measuring and reporting, GOFC-GOLD Report version COP14-2, 48 .

12. Hashimoto, S. (2005) Temperature sensitivity of soil $\mathrm{CO}_{2}$ production in a tropical hill evergreen forest in northern Thailand. J. For. Res., 10, 497-503.

13. IPCC (2000) Land use, land-use change and forestry. In A Special Report of the Intergovernmental Panel on Climate Change, eds. Watson, R. T. et al., Cambridge University Press, Cambridge.

14. Ito, E. et al. (2002) Soil factors affecting the decline of Cryptomeria japonica forest in Kanto plains, Japan. Jpn. J. For. Environ., 44, 37-44 [in Japanese with English summary].

15. Jha, P. \& Mohapatra, K. P. (2010) Leaf litterfall, fine root production and turnover in four major tree species of the semi-arid region of India. Plant Soil, 326, 481-491.

16. Kabeya, N. et al. (2008) Preliminary study of flow regimes and stream water residence times in multi-scale forested watersheds of central Cambodia. Paddy Water Environ., 6, 25-35.

17. Kaspari, M. \& Yanoviak, S. P. (2009) Biogeochemistry and the structure of tropical brown food webs. Ecology, 90, 33423351.

18. Kavvadias, V. A. et al. (2001) Litterfall, litter accumulation and litter decomposition rates in four forest ecosystems in northern Greece. For. Ecol. Manage., 144, 113-127.

19. Kiyono, Y. et al. (2010) Carbon stock estimation by forest measurement contributing to sustainable forest management in Cambodia. JARQ, 44, 81-92.

20. Kiyono, Y. et al. (2011) Practicalities of non-destructive methodologies in monitoring anthropogenic greenhouse gas emissions from tropical forests under the influence of human intervention. $J A R Q, 45,233-242$.

21. Kozlowski, T. T. (1999) Soil compaction and growth of woody plants. Scand. J. For. Res., 14, 596-619.

22. Leff, J. W. et al. (2012) Experimental litterfall manipulation 
drives large and rapid changes in soil carbon cycling in a wet tropical forest. Global Change Biol., 18, 2969-2979.

23. Marthews, T. R. et al. (2008) Soil drying in a tropical forest: three distinct environments controlled by gap size. Ecol. Model., 216, 369-384.

24. Matangaran, J. R. (2006) The recovery of soil compaction in the selection logged over area at Tokyo University Forest in Hokkaido. J. Jpn. For. Eng. Soc., 21, 79-82.

25. Miura, S. et al. (2002) Transport rates of surface materials on steep forested slopes induced by raindrop splash erosion. $J$. For. Res., 7, 201-211.

26. Miura, S. et al. (2003) Protective effect of floor cover against soil erosion on steep slopes forested with Chamaecyparis obtusa (hinoki) and other species. J. For. Res., 8, 27-35.

27. Murdiyarso, D. et al. (2008) How do we measure and monitor forest degradation? In Moving Ahead with REDD: issues, options, and implications, ed. Angelsen, A., CIFOR, Bogor, 99-106. http://www.cifor.cgiar.org/publications/pdf_files/ Books/BAngelsen0801.pdf.

28. Nang, K. et al. (2012) Determination of seasonal change from dry to rainy using wind and precipitation data -Case study of Kampong Thom, central Cambodia-. In Proceedings of International Workshop on Forest Watershed Environment Research in Cambodia 2012, November 2012, Phnom Penh, Cambodia, 11-14.

29. Ohnuki, Y. et al. (2008a) Distribution and characteristics of soil thickness and effects upon water storage in forested areas of Cambodia. Hydrol. Process, 22, 1272-1280.

30. Ohnuki, Y. et al. (2008b) Seasonal change in thick regolith hardness and water content in a dry evergreen forest in Kampong Thom Province, Cambodia. Geoderma, 146, 94101.

31. Ohnuki, Y. et al. (2010) Sediment discharge through buffer zones in a tropical rainforest of Peninsular Malaysia. $J A R Q$, 44, 187-196.

32. Page-Dumroese, D. S. (2006) Soil physical property changes at the North American Long-Term Soil Productivity study sites: 1 and 5 years after compaction. Can. J. For. Res., 36, 551-564.

33. Parsons, S. A. et al. (2012) Regional patterns and controls of leaf decomposition in Australian tropical rainforests. Austral Ecol., 37, 845-854.

34. Pooma, R. (2002) Further notes on Thai Dipterocarpaceae. Thai For. Bull. (Bot.), 30, 7-27.

35. Powers, R. F. (2005) The North American long-term soil productivity experiment: findings from the first decade of research. For. Ecol. Manage., 220, 31-50.

36. Powers, J. S. et al. (2009) Decomposition in tropical forests: a pan-tropical study of the effects of litter type, litter placement and mesofaunal exclusion across a precipitation gradient. J. Ecol., 97, 801-811.

37. Pragasan, L. A. \& Parthasarathy, N. (2005) Litter production in tropical dry evergreen forests of south India in relation to season, plant life-forms and physiognomic groups. Curr. Sci., 88, 1255-1263.

38. Samreth V. et al. (2012) Tree biomass carbon stock estimation using permanent sampling plot data in different types of seasonal forests in Cambodia. JARQ, 46, 187-192.

39. Sawada, H. et al. (2007) Forest environments in the Mekong River basin. Springer, Tokyo, pp. 299.

40. Sayer E. J. (2006) Using experimental manipulation to assess the roles of leaf litter in the functioning of forest ecosystems.
Biol. Rev. Camb. Philos. Soc., 81, 1-31.

41. Sayer, E. J. et al. (2007) Increased litterfall in tropical forests boosts the transfer of soil $\mathrm{CO}_{2}$ to the atmosphere. PLoS One, 2, e1299.

42. Sayer, E. J. \& Tanner, E. V. J. (2010) Experimental investigation of the importance of litterfall in lowland semi-evergreen tropical forest nutrient cycling. J. Ecol., 98, 1052-1062.

43. Sayer, E. J. et al. (2011) Soil carbon release enhanced by increased tropical forest litterfall. Nat. Clim. Change, 1, 304307.

44. Sundarapandian, S. M. \& Swamy, P. S. (1999) Litter production and leaf-litter decomposition of selected tree species in tropical forests at Kodayar in the Western Ghats, India. For. Ecol. Manage., 123, 231-244.

45. Takeda, H. (1984) Comparison of decomposition rates of several tree leaf litter in a tropical forest in the north-east Thailand. Jap. J. Ecol., 34, 311-319.

46. Tani, A. et al. (2007) Principal forest types of three regions of Cambodia: Kampong Thom, Kratie, and Mondolkiri. In Forest environments in the Mekong River basin, eds. Sawada, H. et al., Springer, Tokyo, 201-213.

47. Toriyama, J. et al. (2007) Acrisols and adjacent soils under four different forest types in central Cambodia. Pedologist, 51, 35-49.

48. Toriyama, J. et al. (2008) Comparison of soil physical properties in evergreen and deciduous forests in central Cambodia. J. For. Res., 13, 15-24.

49. Toriyama, J. et al. (2010a) Physicochemical characteristics of plinthic and non-plinthic soils in dry deciduous forests on the east bank of Mekong, Cambodia. Pedologist, 54, 2-10.

50. Toriyama, J. et al. (2010b) Ground-based study on soil carbon stock in forests and rubber plantations in Cambodia. In International Symposium on Forest Monitoring Methodologies for Addressing Climate Change Using ALOS PALSAR, IPB, Bogor, No. 13.

51. Toriyama, J. et al. (2011a) Soil pore characteristics of evergreen and deciduous forests of the tropical monsoon region in Cambodia. Hydrol. Process., 25, 714-726.

52. Toriyama, J. et al. (2011b) Comparison of depth- and massbased approaches for estimating changes in forest soil carbon stocks: A case study in young plantations and secondary forests in West Java, Indonesia. For. Ecol. Manage., 262, 16591667.

53. Toriyama, J. et al. (2011c) Soil carbon stock in tropical monsoon forests in Cambodia. JARQ, 45, 309-316.

54. Vasconcelos, S. S. et al. (2004) Moisture and substrate availability constrain soil trace gas fluxes in an eastern Amazonian regrowth forest. Global Biogeochem. Cy., 18.

55. Veneklaas, E. J. (1991) Litterfall and nutrient fluxes in two montane tropical rain forests, Colombia. J. Trop. Ecol., 7, 319-336.

56. Villalobos-Vega, R. et al. (2011) Leaf-litter manipulations alter soil physicochemical properties and tree growth in a Neotropical savanna. Plant Soil, 346, 385-397.

57. Vitousek, P. M. (1982) Nutrient cycling and nutrient use efficiency. Amer. Natural.. 119, 553-572.

58. Wakita, K. et al. (2004) Digital Geologic Map of East and Southeast Asia, Digital Geoscience Map G-2. Geological Survey of Japan, AIST: Tsukuba.

59. Wood, T. E. et al. (2009) Rain forest nutrient cycling and productivity in response to large-scale litter manipulation. Ecology, 90, 109-121. 
60. Wood, T. E. et al. (2012) Tropical forest carbon balance in a warmer world: a critical review spanning microbial - to ecosystem - scale processes. Biol. Rev.. 87, 912-927.
61. WWF (2008) FIRST CONTACT in the Greater Mekong. Hanoi, Vietnam. http://www.worldwildlife.org/who/media/ press/2008/WWFBinaryitem10994.pdf. 